\title{
Structural characterization and decontamination of dental calculus for ancient starch research
}

\section{Introduction}

Dental calculus analysis has a long tradition of research in prehistory (see early work by Brothwell and Brothwell 1969; Armitage 1975; Dobney and Brothwell 1986). Often containing plant phytoliths (Middleton and Rovner 1994; Lalueza-Fox et al. 1996; Henry and Piperno 2008; Dudgeon and Tromp 2014; Madella et al. 2014), starch granules (Hardy et al. 2009; Li et al. 2010; Wesolowski et al. 2010; Henry et al. 2011; Mickelburgh and Pagan-Jimenez 2012; Buckley et al. 2014; Power et al. 2014; 2015; 2018; Cristiani et al. 2016; 2018), DNA (Weyrich et al. 2015; 2017), microbiomics (Warinner et al. 2015; 2017), proteins (Hendy et al. 2018), and chemical compounds amenable to identification through fingerprinting (Hardy et al. 2012; 2015; 2016b; Warinner et al. 2014), archaeological mineralized plaque offers insights into ancient human ecology, foodways, health, genomics, and palaeodiets.

Ancient dental calculus research currently relies on destructive techniques whereby archaeological specimens are broken down to determine their contents. Two strategies that could partly remediate a permanent loss of the original sample and enhance future analysis and reproducibility include: 1) structural surface characterization through spectroscopy along with crystallographic and spectroscopic analysis of its molecular structure, and 2) surface decontamination protocols in which the efficacy of cleaning dental calculus prior to extraction is demonstrated. In microbotanical research, direct decalcification of the sample, after a cleaning stage variously consisting of soaking in water, immersion in acids, and mechanical dislodgment 
via gas, sonication, and/or toothbrushes (Armitage 1975; Lalueza-Fox et al. 1996; Coil et al. 2003; Boyadjian et al. 2007; Huang et al. 2007; Henry and Piperno 2008; Piperno and Dillehay 2008; Hardy et al. 2009; 2012; Li et al. 2010; Wesolowski et al. 2010; Henry et al. 2011; Buckley et al. 2014; Horrocks et al. 2014; Warinner et al. 2014; Power et al. 2015; 2016; Tao et al. 2015; Tromp and Dudgeon 2015; Tromp et al. 2017) is common. Yet, Weyrich et al. (2015) have noticed that the analysis of microbotanical particles from calculus faces unsolved reproducibility and contamination challenges. Detailed records of starch contamination introduced at the time of excavation through personnel's clothing, motion, wind action, digging implements, sample bags, gloves, and paper products (Mercader et al. 2017) expand on this point. Laboratory contamination reported by Crowther et al. (2014) shows that starch contamination originate from non-powdered and powdered examination gloves, centrifuge tubes, aluminum foil, microscope slides, coverslips, pipettes, air circulation, and floatation and dispersal reagents. Because starch granules are pervasive in environments where calculus samples are excavated, curated, and processed, it is critical to conduct systematic pre-screening to characterize exogenous starch granules before decalcifying, and to consider effective decontamination strategies that will aid in establishing authenticity. While in vivo dental calculus forms in a sheltered environment, there is no empirical basis to assume that archaeological calculus is less prone to contamination than lithics, ceramics, or sediments. As such, ancient calculus is prone to incidental starch contamination prior to burial, while residing in entombing soil and sediment, during excavation and sampling, and in the laboratory.

In this article, we characterize and compare artificial and archaeological dental calculus to elucidate mineral and elemental composition, surface chemistry governing adsorption, crystallinity, formation period, and constituency of trapped organic materials. The lessons learned 
from this comparative characterization formed the basis to develop a decontamination protocol. Archaeological samples of known provenance and curation history served as a proof of concept for ancient starch research.

\section{Materials and methods}

\section{Synthetizing calculus}

All the experimental variables to create artificial calculus are presented in Table 1 . We first collected unmodified potato starch (Red Mill) with the tip of a Pasteur pipette (volumetric, $3 \mathrm{~cm}$ ) and added it to calcium chloride $\left[\mathrm{CaCl}_{2}\right]$ (Fisher C79-500) previously prepared at five different concentrations ( $0.01 \mathrm{~g}, 0.1 \mathrm{~g}, 0.2 \mathrm{~g}, 0.5 \mathrm{~g}$, and $1 \mathrm{~g})$ in $9 \mathrm{ml}$ of water ( $15 \mathrm{ml}$ tube). We vortexed the preparations for 30 seconds. The volume was brought to $10 \mathrm{ml}$ with previously boiled reverse osmosis deionized (RODI) water, and $\mathrm{pH}$ was adjusted to 7-8 using sodium hydroxide [NaOH] (Home Hardware Canada \#3226-431). The tube was vortexed for 2 min. Ammonium phosphate [ $\left.\mathrm{NH}_{4} \mathrm{H}_{2} \mathrm{PO}_{4}\right]$ (Fisher A684-500) at five different concentrations $(0.01 \mathrm{~g}, 0.1 \mathrm{~g}, 0.2 \mathrm{~g}, 0.5 \mathrm{~g}$, and 1 g) received glycine (Sigma-Aldrich, G7126) $(0.01 \mathrm{~g}, 0.1 \mathrm{~g}, 0.2 \mathrm{~g}, 0.5 \mathrm{~g}$, and $1 \mathrm{~g}$ ) and sodium hydroxide to aid in both increasing the $\mathrm{pH}$ and binding properties of the eventual precipitate with starch.

Secondly, we used calcium carbonate blocks (Acros-Organics, CAS: 471.34-1) as a substrate to facilitate calcium phosphate precipitation. These blocks were weighed, rinsed twice with water, and air-dried. Each mixture prepared during step 1 was poured onto the carbonate blocks inside a $50 \mathrm{ml}$ tube, then vortexed for $5 \mathrm{~min}$. Tubes were stored upright for $24 \mathrm{~h}$. The decantation of the supernatant left us with a precipitate at the bottom of the tube, which was transferred to a Petrie dish for $72 \mathrm{~h}$ of air-drying along with the carbonate block. We recorded the 
mass of the precipitated material in grams, appearance, cohesiveness, and starch trapping capacity. Microscopic analysis of the artificial calculus was carried out at 10-40 x with two systems: Motic BA310E / Olympus BX-51.

Several solutions of ammonium phosphate and calcium chloride (0.1\%, $1 \%$ and $2 \%)$ did not yield cohesive precipitates capable of trapping starch granules. Two solutions (5 \% and $10 \%$ ) delivered high cohesion, trapping potato starch granules successfully. However, the $10 \%$ solution generated excessive crystalline growth. Therefore, we selected the $5 \% \mathrm{w} / \mathrm{v}$ concentration for all experiments going forward: structural characterization, comparison with actual dental calculus, and decontamination.

\section{Archaeological controls}

The controls used to optimize our decontamination protocol consisted of two archaeological dental calculus samples from mandibular bone. One tooth (Fig. 1a) came from an individual excavated at the site of El Mirador (Atapuerca, Burgos, Spain) dated to 4760-4200 BP (Vergès et al. 2016). Archaeobotanical studies of the occupation layer suggest a mosaic landscape with forested areas, crop fields, and pastures (Euba et al. 2016; Expósito and Burjachs 2016; Rodríguez et al. 2016). The human remains were exhumed in 2010, but the calculus for this study was extracted in September 2018. The excavation protocols did not include anti-contamination controls and the remains were stored at the Institut Català de Paleoecologia Humana i Evolució Social (Tarragona, Spain). Another tooth (Fig. 2a) came from a human skeleton dating to 810 BP from the rockshelter site of Matangai Turu NW (Democratic Republic of Congo) (Mercader 2002). The dental anthropology was studied by Mercader et al. (2001), and the microbotanical contents of the entombing sediment suggest densely forested environments (Mercader et al. 2000). The human 
remains were excavated in 1993 following standard conditions at the time, but without the awareness that starch contaminants are pervasive in the field (Mercader et al. 2017). As such, dedicated excavation tools, isolated workspace, clean attire, and proven starch free gloves and sample bags were not used. In 1997, the remains were deposited at Universidad Complutense de Madrid, at the Department of Zoology and Physical Anthropology's collection. The dental materials were curated under standard museum conditions, until sampled for ancient calculus research in June 2017.

Archaeological calculus from the two control sets was removed while wearing full body cleanroom coat, hairnet, mask, and starch free gloves, via autoclaved dental picks over ovencleaned $\left(400^{\circ} \mathrm{C}\right)$ aluminum foil. The specimens were placed in previously sterilized centrifuge tubes. By following this procedure, we are certain that no modern starch was introduced by us during the brief time (approximately two hours) during which the sample was removed from the tooth in uncontrolled spaces. Post-removal handling took place in a cleanroom (HEPA class H14) at the University of Calgary, Earth Sciences Building, room no. 811, by placing $0.5 \mathrm{~g}$ of the extracted sample in a $15 \mathrm{ml}$ autoclaved centrifuge tube with $1 \mathrm{ml}$ of previously boiled, RODI water. This was shaken at $90 \mathrm{rpm}$ for five minutes, after which we extracted an aliquot of $0.15 \mathrm{ml}$ containing both calculus fragments and aqueous solution for microscopy at 40x using an Olympus BX51. The processing of control samples under cleanroom conditions allows us to infer that, should there be contaminants on these control samples, it would come from burial sediments and / or excavation, handling, and curation prior to our work.

\section{Structural characterization of synthetic and archaeological dental calculus}


Three methods determined structure and chemistry: Raman spectroscopy (Raman), X-ray photoelectron spectroscopy (XPS), and Powder X-ray Diffraction (P-XRD). Raman delivered structural information near the surface; XPS is also a surface technique penetrating to a depth of a few nanometers, while XRD illuminated the geometry of the bulk material but remained insensitive to surface characterization. Raman and P-XRD were conducted at room conditions (atmospheric pressure, humidity, and temperature), but XPS was executed at room temperature under Ultra High Vacuum (UHV) conditions, and therefore surface structures that depended on the presence of water were changed.

Raman was carried out at the Saskatchewan Structural Sciences Centre (University of Saskatchewan, Canada) on a Renishaw InVia Reflex Raman microscope using a solid state diode laser (Renishaw Inc.) operating at $785 \mathrm{~nm}$ and a 1200 line/mm grating. The microscope was focussed onto the sample using a Leica 20X NPLAN (NA = 0.40) objective, and the backscattered Raman signals were collected with a Peltier cooled CCD detector. Measurements were collected using extended scan or static scan with a 5-10 s detector time. The laser power was $7.8 \mathrm{~mW}$ measured at the sample (archeological samples). The instrument was calibrated using an internal Si (110) sample, which was measured at $520 \mathrm{~cm}^{-1}$. The luminescence profile of the different samples were collected using the $\mathrm{Ar}^{+}$ laser (Modulaser Stellar-Pro) operating at $514 \mathrm{~nm}$. The microscope was focussed onto the sample using a Leica 20X NPLAN (NA = 0.40) objective, and the backscattered luminescence signal were collected with a Peltier cooled CCD detector. The laser power measured at the sample was $4.7 \mu \mathrm{W}$.

XPS is a relative-quantitative spectroscopic method that characterizes chemical elemental composition, constituent ratios, structure, and surface functional groups. All measurements were collected at the Saskatchewan Structural Sciences Centre using a Kratos (Manchester, UK) AXIS Supra system under UHV conditions. This system is equipped with a $500 \mathrm{~mm}$ Rowland circle monochromated Al K- $\alpha(1486.6 \mathrm{eV})$ source and combined hemi-spherical analyzer (HSA) and spherical mirror analyzer 
(SMA). A spot size of 300x700 microns was used for both synthetic samples, as well as the calculus from El Mirador (ATA10MIR201no.609: ATA10MIR). The dental calculus from Matangai Turu NW (MTNW) was too small to use such a large beam size, and thus a diameter slit of 110 microns was used. All survey scan spectra were collected in the -5-1200 binding energy range in $1 \mathrm{eV}$ steps with a pass energy of $160 \mathrm{eV}$. High resolution scans of 4 regions were also conducted using $0.1 \mathrm{eV}$ steps with a pass energy of $20 \mathrm{eV}$. An accelerating voltage of $15 \mathrm{keV}$ and an emission current of $15 \mathrm{~mA}$ were used for the analysis when the large spot size was used, and an acceleration voltage of $15 \mathrm{keV}$ with an emission current of $25 \mathrm{~mA}$ was used for the MTWN sample that used a 110-micron spot size. Data was analyzed using CasaXPS (Version 2.3.18PR1.0).

P-XRD was utilized for the identification of crystalline phase and overall elucidation of 3D atomic, geometric structure. The study was conducted at the Saskatchewan Structural Sciences Centre on a Rigaku Ultima IV X-Ray Diffractometer equipped with a Cu source (1.54056 $\AA$ ), a CBO optical, and a Scintillation Counter detector. The diffractometer was operated at $40 \mathrm{kV}$ and $44 \mathrm{~mA}$. The measurements were carried out on the Multipurpose Attachment, with parafocusing mode. A $\mathrm{K}_{\beta}$ filter (Ni foils) was placed at the receiving end. The synthetic samples were ground to fine powder. The archaeological samples were loosely loaded onto the sample holder without any treatment. $2 \theta$ was scanned from $3^{\circ}$ to $90^{\circ}$ for all the samples (diffraction patterns were reported from $10^{\circ}$ to $90^{\circ}$, since no sharp peaks were present but a broad feature originated from the sample holder). The scan rates were $4^{\circ}$ per minute (step size: $0.02^{\circ}$ ) for the synthetic samples, $1^{\circ}$ per minute (step size: $0.02^{\circ}$ ) for the MTNW sample, and $0.1^{\circ}$ per minute (step size: $0.01^{\circ}$ ) for the ATA10MIR sample.

\section{Contamination and decontamination of synthetic calculus}


To test the decontamination efficacy of different cleaning protocols and rid calculus surfaces of starch contaminants, we first proceeded to contaminate synthetic calculus previously precipitated on calcite blocks. The experimental contamination took place as follows: An aqueous solution of $1 \mathrm{ml}$ containing $0.02 \mathrm{~g}$ of cornstarch and $0.02 \mathrm{~g}$ glycine coated the calcium phosphate precipitate and allowed to dry for $24 \mathrm{~h}$. We video-recorded and photographed the outcome of the contamination sequence at 10 - 40 x via Moticam 5+ and analysed through Motic Images Plus 3.0 and Olympus SC50 (cellSens).

We experimented with four starch-gelatinizing agents previously used in the starch industry (Maher 1983; Yamada et al. 1986; Ragheb et al. 1995; Otsuka et al. 2001; Wang and Wang 2002):

- Sodium hydroxide [NaOH] $(0.1,1$, and $2 \%$ w/v concentration: Home Hardware Canada \#3226-431). $0.01 \mathrm{~g}, 0.1 \mathrm{~g}, 0.2 \mathrm{~g}$ pellets were added to $9 \mathrm{ml}$ of water (15 ml tubes) and vortexed (30 s). The volume was brought up to $10 \mathrm{ml}$ with water. Vials were vortexed again for $30 \mathrm{~s}$.

- Calcium hydroxide $\left[\mathrm{Ca}(\mathrm{OH})_{2}\right](1,2$ and $5 \%$ w/v concentration: Fisher Scientific Canada \#C97-10). $0.1 \mathrm{~g}, 0.2 \mathrm{~g}, 0.5 \mathrm{~g}$ CaOH2 was added to $9 \mathrm{ml}$ of water (15 ml tubes) and vortexed (30s). The volume was brought to $10 \mathrm{ml}$ with water. Vials were vortexed for $30 \mathrm{~s}$.

- EDTA [ $\left.\mathrm{C}_{10} \mathrm{H}_{14} \mathrm{~N}_{2} \mathrm{Na}_{2} \mathrm{O}_{8} \cdot 2 \mathrm{H}_{2} \mathrm{O}\right](0.1,1$ and $2 \% \mathrm{w} / \mathrm{v}$ : disodium salt, dihydrate, crystal, J.T. Baker \#4040). $0.01 \mathrm{~g}, 0.1 \mathrm{~g}, 0.2 \mathrm{~g}$ EDTA were added separately to $9 \mathrm{ml}$ of water (15 ml tubes) and vortexed (30 s). The volume was brought up to $10 \mathrm{ml}$ with water, and $\mathrm{pH}$ adjusted to 8 using sodium hydroxide pellets. Vials were vortexed until the EDTA went into solution. 
- $\alpha$-amylase (0.1, 1 and $2 \% \mathrm{w} / \mathrm{v}$ concentration, $20^{\circ} \mathrm{C}, 500-1500$ units/MG, Bacillus licheniformis, Sigma-Aldrich \#A4551). $0.01 \mathrm{~g}, 0.1 \mathrm{~g}, 0.2 \mathrm{~g}$ amylase were added to $9 \mathrm{ml}$ of water (15 $\mathrm{ml}$ tubes) and vortexed (30 s). The volume was brought up to $10 \mathrm{ml}$ with water, and $\mathrm{pH}$ adjusted to 7-8 using sodium hydroxide pellets. Vials were vortexed for 2 minutes. Unmodified potato (Red Mill) and corn starch (Bakers) were tested in sterilized $15 \mathrm{ml}$ tubes, which received one millilitre of their respective decontaminating solutions. The results were analyzed at time zero $(\mathrm{T}+0)$, one hour $(\mathrm{T}+1 \mathrm{~h})$, six hours $(\mathrm{T}+6 \mathrm{~h}), 24$ hours $(\mathrm{T}+24 \mathrm{~h})$ and seven days $(\mathrm{T}+7 \mathrm{~d})$. Microscopy was carried out with a Motic BA310E / Olympus BX-51: 20-40 x. Micrographs were collected using a Moticam 5+ (software, Motic Images Plus 3.0), and an Olympus SC50 (software, cellSens Standard). Recording took place by scanning one transect five times, repeated over ten separate transects, totalling 50 scans per slide. The measurement of $\mathrm{pH}$ in all solutions was through a ThermoFisher Orion 320 PerpHecT LogR meter, calibrated daily. The $\mathrm{Ag} / \mathrm{AgCl}$ electrode was rinsed after calibration and in between samples.

Experimentation with these four decontamination solutions revealed that the best agent was sodium hydroxide ( $1 \mathrm{ml}, 2 \% \mathrm{w} / \mathrm{v})$ : the precipitate was immersed and left to evaporate over $24 \mathrm{~h}$, then rinsed with water $(5 \mathrm{ml})$ and centrifuged five minutes $(3000 \mathrm{rpm})$ three times. The effectiveness of decontamination was confirmed through light microscopy. The original observation matrix consisting of 5197 images is with the Federated Research Data Repository (doi: 10.20383/101.0121). In addition, a preprint of this article has been uploaded to the Open Science Framework and is available online (doi: 10.31219/osf.io/b4fk6).

\section{Results}


The Raman spectra for synthetic and dental calculus appear in Fig. 3 with all samples showing a characteristic $v_{3}(\mathrm{P}-\mathrm{O})$ symmetric stretch for the $\mathrm{HPO}_{4}{ }^{2-}$ hydroxyapatite band at approximately $960 \mathrm{~cm}^{-}$ ${ }^{1}$ (Koutsopoulos 2002). Two additional regions located at $370-460 \mathrm{~cm}^{-1}$ and $550-630 \mathrm{~cm}^{-1}$ correspond to the $v_{2}(\mathrm{O}-\mathrm{P}-\mathrm{O})$ and $v_{4}(\mathrm{O}-\mathrm{P}-\mathrm{O})$ bending modes of the $\mathrm{PO}_{4}{ }^{3-}$ group. The dental calculus also showed a very broad peak (full width at half maximum, FWHM $>100 \mathrm{~cm}^{-1}$ ) centered at $982 \mathrm{~cm}^{-1}$ (Fig. 4). This broad feature combines vibrational bands from small molecules and perhaps brushite. The dental calculus generated a much larger luminescence spectral profile compared to synthetic calculus (Fig. 5), also indicating differences in small molecule composition. The synthetic calculus samples (Fig. 3-5) showed brushite with a $v_{3}(\mathrm{P}-\mathrm{O})$ symmetric stretch centered at $987 \mathrm{~cm}^{-1}$. The FWHM for this peak was $8-16 \mathrm{~cm}^{-1}$. The bending mode vibrations is located within the same region as the hydroxyapatite. There is also a series of bands typical of carbohydrates derived from the trapped potato starch granules (Figure 3), including a sharp band at $478 \mathrm{~cm}^{-1}$ (ring skeletal mode), peaks at $860 \mathrm{~cm}^{-1}$ and $940 \mathrm{~cm}^{-1}$ (C-O-C / CO-H stretching vibrations for $\alpha-1,4$ glycosidic linkages) and a band at $2910 \mathrm{~cm}^{-1}$ (C-H stretching) (Mathlouthi and Koenig 1987; De Gelder et al. 2007).

XPS survey of synthetic and actual dental calculus shows their elemental breakdown (Table 2): carbon, oxygen, calcium, and phosphorus. Aluminum, silicon, nitrogen, sodium, and chlorine appear in small quantities (Fig. 6). The Ca:P ratio for archaeological dental calculus is 2:1-1:7 which could indicate hydroxyapatite. On the other hand, synthetic samples have Ca:P ratios close to 1 suggesting a di-calcium phosphate such as brushite $\left[\mathrm{CaHPO}_{4}\right.$ or $\left.\mathrm{CaHPO}_{4} 2 \mathrm{H}_{2} \mathrm{O}\right]$. High resolution XPS was collected for the following primary regions C1s (carbon)(Fig. 7), O1s (oxygen)(Fig. 8), Ca2p (calcium)(Fig. 9) and P2p (phosphorus)(Fig. 10)(Table 3). In both archaeological and synthetic samples a peak around $284.8 \mathrm{eV}$ indicates $\mathrm{C}-\mathrm{C} / \mathrm{CH}$, and in one of the two synthetic samples (6.84) the $\mathrm{C}-\mathrm{O}-\mathrm{C}$ and/or C-N bonds are very prominent (286.1 eV). (The other samples exhibit this bond, but not to the same extent.) All 
materials show an abundance of carbon (288-289 eV), which is indicative of $\mathrm{COOH}$ groups. These organic functional groups are present in carbohydrates and proteins. A small amount of $\mathrm{CO}_{3}$ also appears in one archaeological (ATA10) and one synthetic sample (6.85). The O1s spectra of all samples are fairly similar - essentially 2 peaks, with the peak at the lowest energy $(\sim 531 \mathrm{eV})$ being the most intense: This is the oxygen that would be found in calcium phosphate $\left[\mathrm{Ca}_{x}\left(\mathrm{PO}_{4}\right)_{y}\right]$. The second and less intense peak (532-533 eV) represents oxygen attached to carbon in $\mathrm{CO}, \mathrm{COOH}$, and $\mathrm{COC}$. The phosphorus and calcium spectra of all samples are essentially the same. They indicate one type of $\mathrm{P}$ and $\mathrm{Ca}\left[\mathrm{Ca}_{x}\left(\mathrm{PO}_{4}\right)_{y}\right]$.

P-XRD patterns of calculus appear in Fig. 11. The major peaks in synthetic calculus are very similar to each other (Fig. 11a / 11b), and so are those from archaeological samples (Fig. 11c / 11d); thus, synthetic and archaeological samples support different crystalline phases. The peaks in ancient calculus are broad, which is likely due to a large crystal size. To identify these phases, the P-XRD pattern was loaded to MDI Jade 2010, which performed baseline corrections and background noise removal. The software then matched peaks against the incorporated database (COD, AMCSD, MDI-500) (Downs and Hall-Wallace 2003; Grazulis et al. 2009). A whole pattern fitting (WPF) and a Rietveld Refinement determined the composition of each phase (Table 4, Fig. 12). These show that synthetic samples are brushite (Brown et al. 1962; Schroeder et al. 1977; Schofield et al. 2004), while the archaeological calculus is hydroxyapatite (Sudarsanan and Young 1969). In sum, the materials characterization shows that our brushite-rich synthetic precipitates mimic the early mineralization process that occurs in the oral cavity prior to the stabilization of hydroxyapatite crystallizations (Hayashizaki et al. 2008).

Experimental contamination of synthetic calculus and de-facto contamination of archaeological calculus 
Synthetic brushite fragments ( $\bar{x} 1.12 \mathrm{~mm}$; $\mathrm{n}=100)$ were deposited in sterilized petri dishes for contamination with $1 \mathrm{ml}$ of corn-glycine mix (2\% w/v). Corn granules covered $>95 \%$ of the surface matrix across variable topographies: elevated, flat, depressed, and fissured micro-regions (Fig. 13). Except for crevices, we saw no evidence that contaminant corn granules penetrated the carbonatic matrix where the resident potato starch granule population are consistently distinguished from the adsorbed, overlying contaminants.

As for the contamination potential of archaeological dental calculus by starch granules and other exogenous materials, we recorded 204 contaminant particles in two samples, with $90 \%$ of these contaminants being starch granules (Fig. 1, 2). Contamination was detected through microscopy of two aliquots from each control: at Matangai Turu NW we tallied 170 remains (starch granules, $\mathrm{n}=166$; phytoliths, $\mathrm{n}=4$ ), while we recorded 34 particles on the sample from El Mirador, of which 18 are starch granules, 15 are phytoliths, and 1 micro-remain is charcoal. Four lines of evidence support the exogenous nature of these particles:

1. Homogenous starch assemblage with morphometric and textural qualities consistently overlapping with demonstrated field and lab contaminants such as maize and wheat (Fig 2b-as, at)(Crowther et al. 2014; Mercader et al. 2017) in the case of Matangai Turu NW. The calculus sample from El Mirador was coated with granules (Fig. 1) resembling natural starches from soil assemblages (Mercader et al. 2017).

2. Systematic lack of association with dental calculus: The starch granules are not trapped in the calcium phosphate matrix. Even in cases where starch granules appear to adhere to the periphery of calculus (Fig. 2 d, e, f, m, t, y, z, aa, ab, ag, ai, at, au, av, aw), this is an optical effect, with granules floating away from the calculus when a probe causes their dislodgment (Fig. 2at, au). 
3. The maize and wheat granules display morphometrics unlike those from the starch granules genuinely trapped in the dental calculus (Fig. 2ay), and optically display the features that come from intact amylopectin crystallites in pristine conditions: full birefringence and Maltese cross (e.g. Fig. 2u, ad). The starches from El Mirador display the typical damage features from microbial decay that happen during burial (Haslam 2004) (Fig. 1b-e): disruption of crystallites, centric implosion, pitting, and fissuring.

4. Demonstrated transfer of other microbotanical particles such as phytoliths (Fig. 2az-bc) (Fig. 1p-v)(Matangai Turu NW, $\mathrm{n}=4$; El Mirador, $\mathrm{n}=15$ ) from the entombing sediment to the calculus surface: they remain loose on the surface, not trapped inside calculus.

\section{Decontamination effect from calcium hydroxide, sodium hydroxide, EDTA, and $\alpha$-amylase}

Calcium hydroxide: this solution was tested using three concentrations (1\%, $2 \%$ and $5 \%$ w/v) (Table 5), with pH 12.45-12.55:

- Potato starch granules (Fig. 14): All concentrations caused clefting, radial fissuring, and implosion of the granules for immersions up to $24 \mathrm{~h}$. Implosion and disarticulation were extreme in the longest immersion ( $\mathrm{T}+7 \mathrm{~d}$ ), noticing gelatinization and leaching (Table 5).

- Corn starch granules (Fig. 15): almost all granules (> $99 \%$ ) remained intact while a very low number (0.81 \%, 49 granules; $\mathrm{n}=6000)$ showed minor radial fissuring and implosion in the experiments that lasted $24 \mathrm{~h} /$ seven days (2 \% - $5 \% \mathrm{w} / \mathrm{v}$ ) (Table 5).

Sodium hydroxide: Tested at $0.1 \%, 1 \%$ and $2 \%$ w/v concentrations with pH 12.55-13.35:

- Potato starch granules: marked swelling and partial gelatinization occurred even at low concentration. At $0.1 \%$ and $1 \% \mathrm{w} / \mathrm{v}$ starch granule ghosts become apparent at T+24 h (1\% w/v) and T+7 d (0.01\% w/v). (The external layers of starch granules form granule envelopes when 
gelatinized, which in the field of carbohydrate polymers are referred to as ghosts: e.g. Atkin et al. 1998; Zhang et al. 2014.) Complete gelatinization happened at $1 \% \mathrm{w} / \mathrm{v}$ and leaching at $\mathrm{T}+0 \geq$ $2 \% \mathrm{w} / \mathrm{v}$ (Table 5).

- Corn starch granules: at the lowest concentration $(0.1 \% \mathrm{w} / \mathrm{v})$, granules underwent minor radial fissuring and gelatinization at $\mathrm{T}+7 \mathrm{~d}$, while gelatinization took place at $1 \% \mathrm{w} / \mathrm{v}$, and leaching at $2 \% \mathrm{w} / \mathrm{v}(\mathrm{T}+0)$ (Table 5$)$.

EDTA: Mixes at $0.1 \%, 1 \%$ and $2 \% \mathrm{w} / \mathrm{v}$ received $0.05-1.25 \mathrm{~g}$ of sodium hydroxide to stabilize $\mathrm{pH}$ at 8.0, given that EDTA must be deprotonated to go into solution:

- Potato starch granules (Fig. 16): 150 granules (11\%, n=1344) suffered radial fissuring and implosion in all concentrations $>1 \mathrm{~h}$ (Table 5).

- Corn starch granules (Fig. 17): no damage was observed. Slight gelatinization occurred in 91 granules $(n=2000,5 \%)$ that were immersed several hours $(T+1 h, T+6 h)$ at the highest concentration (2\% w/v) (Table 5).

$\alpha$-amylase: the starch degradation potential of this enzyme was tested at $0.1 \%, 1 \%$ and $2 \% \mathrm{w} / \mathrm{v}$ concentrations $(\mathrm{pH} 6.12-6.72)$ at $20^{\circ} \mathrm{C}$. Higher temperatures $\left(30^{\circ} \mathrm{C}-70^{\circ} \mathrm{C}\right)$ conducive to maximum activity (Helbert et al. 1996; Goyal et al. 2005) were not used, given the structural changes heat induces to starch.

- Potato starch granules (Fig. 18): we noted radial fissuring, implosion, lamellae disruption, disarticulation, and loss of birefringence in 5-20 minutes (all concentrations). Although the structural damage seemed extreme, especially for the longest immersion times, no granule ghosts could be detected (Table 5).

- Corn starch granules (Fig. 19): in our lowest concentration (0.1 \% w/v) granules were not affected except for $\mathrm{T}+24 \mathrm{~h}$ and $\mathrm{T}+7 \mathrm{~d}$. Solutions at $1 \%$ and $2 \% \mathrm{w} / \mathrm{v}$, however, led to radial 
fissuring and disarticulation in $0.1 \%$ of the granules $(\mathrm{n}=1000)$. We did not notice granule ghosts (Table 5).

\section{Discussion}

This is the first attempt at creating synthetic calculus to understand and systematically test effective decontamination protocols for ancient starch research. We understand the limitations of our microcosm, and the important differences between natural, synthetic, and archaeological calculus. Dental plaque is an open system mediated by bacteria ( $>500$ strains) resulting in a highly heterogeneous structure and a variety of calcium phosphate mineral phases (Rizzo et al. 1963;

Grøn et al. 1967; Rosan and Lamont 2000). Moreover, environmental conditions (pH and temperature) determine elemental composition, crystallization rates (Hoyer et al. 1984; Abraham et al. 2005), and recrystallization (Hayashizaki et al. 2008).

However, the materials science characterization we conducted shows that synthetic calculus is a good proxy for archaeological dental calculus research along the following lines:

1. Elemental composition and surface functional groups on synthetic and archaeological surfaces dictate molecular adsorption and therefore the attachment of contaminants. All samples show a peak at $284.8 \mathrm{eV}$ indicative of $\mathrm{C}-\mathrm{C} / \mathrm{CH}$. Artificial and natural calculus both show an abundance of carbon around 288-289 $\mathrm{Ev}$ [COOH groups]. A small amount of $\mathrm{CO}_{3}$ also appears in archaeological and synthetic samples. The O1s spectra are similar. In addition, the phosphorus and calcium spectra of all samples are practically identical.

2. Our artificial matrices are dominated by the mineral brushite $\left[\mathrm{CaHPO}_{4} * 2 \mathrm{H}_{2} \mathrm{O}\right]$ and are equivalent to calculus formed during early depositional stages, up to three months; morphologically, in terms of crystalline phase, but also in the limited amount of impurities 
such as aluminum, sodium, and chlorine (Hoyer et al. 1984). Although Raman indicated apatitic phases in the synthetic materials (cf. Tsuda and Arends 1993), it must be noted that brushite is acidic and unstable in aqueous solutions and readily transforms to apatitic forms in basic solutions (Tas 2016). This would explain the identification of brushite through XPS under UHV (water absent), while Raman identified brushite/apatite (water preserved under room conditions). The archaeological calculus is mostly hydroxyapatite $\left[\mathrm{Ca}_{10}\left(\mathrm{PO}_{4}\right)_{6}(\mathrm{OH})_{2}\right]$ with traces of brushite, since the tail of its band covers the $980 \mathrm{~cm}^{-1}$ region. Apatite in dental calculus materializes between eight months to a year (Jensen and Danø 1954; Jensen and Rowles 1957; Rowles 1964; Schroeder and Bambauer 1966; Swärdstedt 1966; Driessens and Verbeeck 1988; Kodaka et al. 1988; Abraham et al. 2005; Charlier et al. 2010). No octacalcium phosphate [Ca8 $\mathrm{H}_{2}\left(\mathrm{PO}_{4}\right)_{6} * 5 \mathrm{H}_{2} \mathrm{O}$ ] or whitlocktite $\left[(\mathrm{CaMg})_{3}\left(\mathrm{PO}_{4}\right)_{2}\right]$ were detected.

3. Dental calculus has large crystals as shown by Raman, XPS, and P-XRD, and therefore it is highly mineralized and presents low solubility compared to samples of synthetic brushite (Tas 2016). Crystallinity governs permeation and chelation with outside solutes. That is, at higher crystallinity in calcium phosphates, the greater the cohesiveness and resistance to damage and stoichiometric solution will be.

Archaeological dental calculus provides ancient starch research a niche where granules may be adsorbed to minerals, coated, overgrown, entrapped, or protected from chemical degradation (Mercader et al. 2018). While encapsulation offers protection from degradation, it does not shield the sample's surface from contamination. When designing our experimental contamination process, we pursued a holistic approach inclusive of diverse contamination scenarios and vectors in ancient starch research (Laurence et al. 2011; Crowther et al. 2014; 
Mercader et al. 2017; 2018). We used native starches admixed with co-concurrent molecules (e.g. amino acids) to follow current expectations when conceptualizing starch diagenetic processes (see review in Mercader et al. 2018). Potato and corn are well known structurally (Pérez et al. 2009; Huang et al. 2015), are accessible for reproducibility, and have variable crystallinity (Whittam et al. 1990; Perez and Bertoft 2010). In addition, the granules from these two species are distinguishable from one another by morphometrics (Jane et al. 1994), are structurally resistant (Gallant et al. 1997), and known widespread contaminants (Crowther et al. 2014; Power et al. 2014; García-Granero et al. 2016; Mercader et al. 2017; Copeland and Hardy 2018).

The various chemical decontamination mixtures we tested caused visible changes to starch granules: implosion, clefting, loss of birefringence, radial fissuring, disarticulation, gelatinization, leaching, and granule ghosts. Does the proposed decontamination protocol permeate and thus damage the endogenous starch granules trapped inside calcium phosphate matrices? The permeability of dental calculus has long been demonstrated, and reports of solute infiltration confirm an open system (Kleinberg 1970; Baumhammers et al. 1973). Hydrothermally-mediated hydrolysis of calcium phosphate in the presence of water and bases is also well established in dental calculus research (Tas 2016), especially in the presence of sodium hydroxide (Furutaka et al. 2006; Abdel-Aal et al. 2013), which hydrolyses brushite to apatite, octacalcium phosphate, and whitlocktite almost immediately: Raman demonstrated the apatitic trend of brushite when mixed with water.

The sodium hydroxide-based protocol put forward in this paper triggers two concurrent reactions: 1) gelatinization of exogenous starch granules located outside or on the surface of dental calculus (Fig. 20a/b) and 2) transformation of brushitic surface into higher order, apatitic recrystallization (Fig. 21e, g, h). These reactions consume most of the sodium hydroxide from the 
system and disable its starch gelatinizing capability shortly, which implies that starch granules trapped inside calculus or those that developed a Ca:P cast (Fig. 21a-f) maintain their structure, showing unaltered native features such as size, birefringence, lamellae, and Maltese cross (Fig. 21h-j). Contrarily, exogenous starch granules do not have a protective Ca;P shield become targets for gelatinization (Fig. 20b).

Not all researchers describe their decontamination methods and the effect of their cleaning protocols on contaminant starch granules. Cleaning standards include:

1. Immersion in water to remove phytolith/starch-bearing soil particles from the excavation context (Armitage 1975), sometimes aided by a brush (Lalueza-Fox et al. 1996; Li et al. 2010; Mickelburgh and Pagan-Jimenez 2012) and/or ultrasonics (Li et al. 2010; Madella et al. 2014).

2. Mechanical dislodgment of loose particles with brushes (Wesolowski et al. 2010; Blatt et al. 2011; Dudgeon and Tromp 2014; Power et al. 2014; 2015) plus compressed air (Charlier et al. 2010). Note that brushing is often conducted dry (Wesolowski et al. 2010; Blatt et al. 2011; Power et al. 2014; 2015; 2018).

3. 'Chemical peel' via immersion in hydrochloric acid (5-20\%) for several minutes (Hardy et al. 2009; 2012; 2016a; Blatt et al. 2011; Buckley et al. 2014).

Little is known about the efficiency of these methods for a complete removal of sediment/soil and unrelated microbotanical matter. Generally, mechanical cleaning such as the one accomplished with a toothbrush, is unlikely to remove exogenous starches: brushing failed to remove the totality of maize starch granules from synthetic matrices (Fig. 22). Even partial surface dissolution by acid over short times has unknown effectiveness in removing all starch granules that exist over the entire surface topography, including deep fissures. Apatite and whitlocktite have structural 
weaknesses (Dorozhkin 2012). Acid is likely to etch microtopographic irregularities of varying cohesiveness differentially, affecting some spots but not others; because of crevices (>200 $\mu \mathrm{m})$ and inter-crystal pore size and orientation, anomalies in crystallization, different calcium / phosphate ratios, and intra-crystalline nucleation of $\mathrm{Fe}$ and $\mathrm{Mg}$ (Wolstenholme and O'Connor 2009; Dorozhkin 2011). Thus, without direct evidence that a given sample was not contaminated before decalcifying, it is impossible to predict how effective cleaning methods that use the dissolution of carbonate-bound starch contaminants from calculus surfaces are; especially when using weak acid solutions for only a few minutes. We cannot recommend water rinses alone as a decontamination method, such as the one put forward by Tavarone et al. (2018). While this method may work in situations where the only proven contamination source are cornstarch granules from powdered gloves (cf. Laurence et al. 2011; Crowther et al. 2014; Mercader et al. 2017; 2018), we note that the starch utilized in the glove industry are modified, not native. They are cross-linked (Osman and Jensen 1999; Swanson and Ramalingam 2002), and the industry's goal when chemically changing corn starch for gloves is to have water-washable granules with altered viscosity and absorption, while maintaining lubrication. That is, water rinses might not detach contamination from native starch, which can adsorb to surfaces and is reported to require several ultrasonication cycles to dislodge from archaeological and experimental tools (Pedergnana et al. 2016; Cnuts and Rots 2017; Mercader et al. 2017). We also wanted certainty in decontamination efficiency, through a worst-case scenario that would include varied potential contamination sources, not just gloves, and chemical adsorption to surfaces, versus superficial coating from modified, strengthened starches industrially designed to dust off by rinsing (cf. Tavarone et al. 2018).

\section{Conclusion}


This work is a first step towards developing a starch decontamination protocol that is safe for archaeological dental calculus. Synthetic calculus allows for isolating, and therefore understanding, all potential variables from the onset. This is opposed to introducing the multitude of unknowns typical of dental calculus, which is characteristically highly variable with a polygenic matrix that varies from individual to individual in regards to mineralogy, crystalline system, and microstructure. It is unethical to destroy archaeological samples without first experimenting on proxies and providing a full characterization of the materials that records elemental composition, surface chemistry, formation period, and organic constituency of trapped materials. Efficient decontamination of calculus samples prior to decalcification requires a protocol that eradicates starch granules across surfaces and crevices within the open microcrystalline structure of dental calculus. We arrived at a procedure that disintegrates exogenous starch granules from all faces and fissures without damaging the calcium phosphate matrix or the entrapped microbotanical remains. This method calls for a $24 \mathrm{~h}$ immersion of dental calculus in $1 \mathrm{ml}$ of sodium hydroxide of $2 \% \mathrm{w} / \mathrm{v}$ solution. The decontamination process is neutralized by immersion in $14 \mathrm{ml}$ of water three times, prior to decalcification. Our synthetic precipitates are comparable to those occurring in the oral cavity before the hydroxyapatite crystals mature, and are weakly mineralized. Therefore, we expect no damage to archaeological specimens given their higher cohesiveness. Future work should characterize dental calculus at the structural level before engaging in destructive techniques. This creates a permanent record for future use that will enhance reproducibility. Material science will help us select the best possible method to dissolve variable calcium phosphate surface chemistry, mineralogy, and crystallinity, each with unique stoichiometric properties. In addition, researchers must screen samples under the microscope to document 
contaminant starch granules prior to the dissolution of calculus, recording results before and after decontamination.

Funding: This work was sponsored by the Canadian Social Sciences and Humanities Research Council under its Partnership Grant Program no. 895-2016-1017. The Saskatchewan Structural Sciences Centre (SSSC) is acknowledged for providing facilities to conduct this research. Canada Foundation for Innovation, Natural Sciences and Engineering Research Council of Canada and the University of Saskatchewan support research at the SSSC. The following Spanish institutions and grants made this work possible: MINECO/FEDER: CGL2015-65387-C03-1-P, Generalitat de Catalunya: 2017SGR1040 (URV: 2016PFR-URVB2-17). Junta de Castilla y León, and Fundación Atapuerca.

\section{References}

Abdel-Aal EA, El-Sayed D, Shoeib M, Kandil AT (2013) Enhancing coating of brushite/hydroxyapatite layer on titanium alloy implant surface with additives. Appl Surf Sci 285:136-143

Abraham J, Grenon M, Sánchex HJ, Pérez C, Barrea R (2005) A case study of elemental and structural composition of dental calculus during several stages of maturation using SRXRF. Journal of Biomedical Materials Research Part A: An Official Journal of The Society for Biomaterials, The Japanese Society for Biomaterials, and The Australian Society for Biomaterials and the Korean Society for Biomaterials 75:632-628 https://doi.org/10.1002/jbm.a.30484

Armitage RA (1975) The extraction and identification of opal phytoliths from the teeth of ungulates. J Archaeol Sci 2:187-197 https://doi.org/10.1016/0305-4403(75)90056-4

Atkin NJ, Abeysekera RM, Robards AW (1998) The events leading to the formation of ghost remnants from the starch granule surface and the contribution of the granule to the gelatinization endotherm. Carbohydr Polym 36:193-204 https://doi.org/10.1016/s01448617(98)00002-2

Baumhammers A, Conway JC, Saltzberg D, Matta RK (1973) Scanning electron microscopy of supragingival calculus. J Periodontol 44:92-95

Blatt SH, Redmond BG, Cassman V, Sciulli PW (2011) Dirty teeth and ancient trade: evidence of cotton fibres in human dental calculus from Late Woodland, Ohio. Int J Osteoarchaeol 21:669-678 https://doi.org/10.1002/oa.1173

Boyadjian CHC, Eggers S, Reinhard K (2007) Dental wash: a problematic method for extracting microfossils from teeth. J Archaeol Sci 34:1622-1628 https://doi.org/10.1016/j.jas.2006.12.012

Brothwell DR, Brothwell P (1969) Food in Antiquity: A Survey of the Diet of Early Peoples. Thames and Hudson, London

Brown WE, Smith JP, Lehr JR, Frazier AW (1962) Octacalcium phosphate and hydroxyapatite: crystallographic and chemical relations between octacalcium phosphate and hydroxyapatite. Nature 196:1050-1055

Buckley S, Usai D, Jakob T, Radini A, Hardy K (2014) Dental calculus reveals unique insights into food items, cooking and plant processing in Prehistoric Central Sudan. PLoS One 9:e100808 https://doi.org/10.1371/journal.pone.0100808 
Charlier P, Huynh-Charlier I, Munoz O, Billard M, Brun L, de la Grandmaison GL (2010) The microscope (optical and SEM) examination of dental calculus depositis (DCD). Potential interest in forensic anthropology of a bio-archaeological method. Leg Med 12:162-171 https://doi.org/10.1016/j.legalmed.2010.03.003

Cnuts D, Rots V (2017) Extracting residues from stone tools for optical analysis: towards in experiment-based protocol. Archaeol Anthropol Sci 10:1717-1736 https://doi.org/10.1007/s12520-017-0484-7

Coil J, Korstanje MA, Archer S, Hastorf CA (2003) Laboratory goals and considerations for multiple microfossil extraction in archaeology. J Archaeol Sci 30:991-1008 https://doi.org/10.1016/s0305-4403(02)00285-6

Copeland L, Hardy K (2018) Archaeological starch. Agronomy 8:4 https://doi.org/10.3390/agronomy801000

Cristiani E, Radini A, Borić D, Robson HK, Caricola I, Carra M, Mutri G, Oxilia G, Zupancich A, Šlaus M, Vujević D (2018) Dental calculus and isotopes provide direct evidence of fish and plant consumption in Mesolithic Mediterranean. Sci Rep 8:8117

Cristiani E, Radini A, Edinborough M, Borić D (2016) Dental calculus reveals Mesolithic foragers in the Balkans consumed domesticated plant foods. Proc Natl Acad Sci 113:10298-10303 https://doi.org/10.1073/pnas.1603477113

Crowther A, Haslam M, Oakden N, Walde D, Mercader J (2014) Documenting contamination in ancient starch laboratories. J Archaeol Sci 49:90-104

De Gelder J, De Gusseum K, Vandenabeele P, Moens L (2007) Reference database of Raman spectra of biological molecules. J Raman Spectrosc 38:1133-1147

Dobney K, Brothwell D (1986) Dental calculus: its relevance to ancient diet and oral ecology. In: Olsen S (ed) Teeth and Anthropology. vol 291. Archeopress, Oxford, pp 55-81

Dorozhkin SV (2011) Calcium orthophosphates: occurrence, properties, biomineralization, pathological calcification and biomimetic applications. Biomatter 1:121-164 https://doi.org/10.4161/biom.18790

Dorozhkin SV (2012) Amorphous calcium orthophosphates: nature, chemistry and biomedical applications. Int J Mater Chem 2:19-46 https://doi.org/10.5923/j.ijmc.2012201.04

Downs RT, Hall-Wallace M (2003) The American mineralogist crystal structure database. Am Mineral 88:247-250

Driessens FCM, Verbeeck R (1988) Relation between physio-chemical solubility and biodegradability of calcium phosphates. In: Putter C (ed) Implant Materials in Biofunction. Elsevier, Amsterdam, pp 105-111

Dudgeon JV, Tromp M (2014) Diet, geography and drinking water in Polynesia: microfossil research from archaeological human dental calculus, Rapa Nui (Easter Island). Int J Osteoarchaeol 24:634-648 https://doi.org/10.1002/oa.2249

Euba I, Allue E, Burjachs F (2016) Wood uses at El Mirador Cave (Atapuerca, Burgos) based on anthracology and dendrology. Quatern Int 414:285-293 https://doi.org/10.1016/j.quaint.2015.08.084

Expósito I, Burjachs F (2016) Taphonomic approach to the palynological record of burnt and unburnt samples from El Mirador cave (Sierra de Atapuerca, Burgos, Spain). Quatern Int 414:258-271 https://doi.org/10.1016/j.quaint.2016.01.051

Furutaka K, Monma H, Okura T, Takahashi S (2006) Characteristic reaction processes in the system brushite-NaOH solution. J Eur Ceram Soc 26:543-547 
Gallant DJ, Bouchet B, Baldwin PM (1997) Microscopy of starch: evidence of a new level of granule organization. Carbohydr Polym 32:177-191 https://doi.org/10.1016/s01448617(97)00008-8

García-Granero JJ, Lancelotti C, Madella M, Ajithprasad P, Crowther A, Korisettar R, Weisskopf A (2016) Millet and herders: the origins of plant cultivation in semi-arid North Gujarat (India). Curr Anthropol 57:149-173 https://doi.org/10.1086-685775

Goyal N, Gupta JK, Soni SK (2005) A novel raw starch digesting thermostable $\alpha$-amylase from Bacillus sp. I-3 and its use in the direct hydrolysis of raw potato starch. Enzyme Microb Technol 37:723-734 https://doi.org/10.1016/j.emzmitec.2005.04.017

Grazulis S, Chateigner D, Downs RT, Yokochi AT, Quiros M, Lutterotti L, Manakova E, Butkus J, Moeck P, Le Bail A (2009) Crystallography open database: an open-access collection of crystal structures. J Appl Crystallogr 42:726-729

Grøn P, Van Campen GJ, Lindstrom I (1967) Human dental calculus: inorganic chemical and crystallographic composition. Arch Oral Biol 12:829-837 https://doi.org/10.1016/00039969(67)90105-7

Hardy K, Blakeney T, Copeland L, Kirkham J, Wrangham R, Collins M (2009) Starch granules, dental calculus and new perspectives on ancient diet. J Archaeol Sci 36:248-255

Hardy K, Brand-Miller J, Brown KD, Thomas MG, Copeland L (2015) The importance of dietary carbohydrate in human evolution. Q Rev Biol 90:251-268 https://doi.org/10.1086-682587

Hardy K, Buckley S, Collins M, Estalrrich A, Brothwell D, Copeland L, García-Taberno A, García-Vargas S, de la Rasilla M, Lalueza-Fox C, Huguet R, Bastir M, Santamaría D, Madella M, Wilson J, Cortés AF, Rosas A (2012) Neanderthal medics? Evidence for food, cooking, and medicinal plants entrapped in dental calculus. Naturwissenschaften 99:617626

Hardy K, Radini A, Buckley S, Blasco R, Copeland L, Burjachs F, Girbal J, Yll R, Carbonell E, María Bermúdez de Castro J (2016a) Diet and environment 1.2 million years ago revealed through analysis of dental calculus from Europe's oldest hominin at Sima del Elefante, Spain. Sci Nat 104 https://doi.org/doi:10.1007/s00114-016-1420-X

Hardy K, Radini A, Buckley S, Sarig R, Copeland L, Gopher A, Barkai R (2016b) Dental calculus reveals potential respiratory irritants and ingestion of essential plant-based nutrients at Lower Palaeolithic Qesem Cave, Israel. Quatern Int 398:129-135 https://doi.org/10.1016/j.quaint.2015.04.033

Haslam M (2004) The decomposition of starch grains in soils: implications for archaeological residue analyses. J Archaeol Sci 31:1715-1734

Hayashizaki J, Ban S, Nakagaki H, Okumura A, Yoshii S, Robinson C (2008) Site specific mineral composition and microstructure of human supra-gingival dental calculus. Arch Oral Biol 53:168-174 https://doi.org/10.1016/j.archoralbio.2007.09.003

Helbert W, Schülien M, Henrissat B (1996) Electron microscope investigation of the diffusion of Bacillus licheniformis $\alpha$-amylase into corn starch granules. Int J Biol Macromol 19:165169 https://doi.org/10.1016/041-8130(96)01123-3

Hendy J, Warinner C, Bouwman A, Collins MJ, Fiddyment S, Fischer R, Hagan R, Hofman CA, Holst M, Chanes E, Klaus L (2018) Proteomic evidence of dietary sources in ancient dental calculus. Proc R Soc Lond (Biol) 285:20180977 https://doi.org/10.1098/rspb.2018.0977

Henry AG, Brooks AS, Piperno DR (2011) Microfossils in calculus demonstrate consumption of plants and cooked foods in Neanderthal diets (Shanidar III, Iraq; Spy I and II, Belgium). Proc Natl Acad Sci 108:486-491 https://doi.org/10.1073/pnas.1016868108 
Henry AG, Piperno DR (2008) Using plant microfossils from dental calculus to recover human diet: a case study from Tell al-Raqa'i, Syria. J Archaeol Sci 35:1943-1950 https://doi.org/10.1016/j.jas.2007.12.005

Horrocks M, Nieuwoudt MK, Kinaston R, Buckley H, Bedford S (2014) Microfossil and Fourier Transform InfraRed analyses of Lapita and post-Lapita human dental calculus from Vanuatu, Southwest Pacific. J Roy Soc New Zeal 44:17-33 https://doi.org/10.1080/03036758.2013.842177

Hoyer I, Gaengler P, Bimberg R (1984) In vivo remineralization of human enamel and dental $\begin{array}{lllll}\text { calculus formation. } & \mathrm{J} & \text { Dent } & \text { Res:1136-1139 }\end{array}$ https://doi.org/10.1177/00220345840630090801

Huang TT, Zhou DN, Jin ZY, Xu XM, Chen HQ (2015) Effect of debranching and heat-moisture treatments on structural characteristics and digestibility of sweet potato starch. Food Chem 187:218-224 https://doi.org/10.1016/j.foodchem.2015.04.050

Huang ZQ, Lu JP, Li XH, Tong ZF (2007) Effect of mechanical activation on physico-chemical properties and structure of cassava starch. Carbohydr Polym 68:128-135 https://doi.org/10.1016/j.carbpol.2006.07.017

Jane J-L, Kasemsuwan T, Leas S, Zobel H, Robyt JF (1994) Anthology of starch granule morphology by Scanning Electron Microscopy. Starch-Stärke 46 https://doi.org/10.1002/star.19940460402

Jensen AT, Danø M (1954) Crystallography of dental calculus and the precipitation of certain $\begin{array}{lllll}\text { calcium } & \text { phosphates. } & \mathrm{J} & \text { Dent } & \text { Res }\end{array}$ https://doi.org/10.1177/00220345540330060201

Jensen AT, Rowles SL (1957) Magnesian whitlockite, a major consituent of dental calculus. Acta Odontol Scand 15:121-139 https://doi.org/10.3109/00016355709041096

Kleinberg I (1970) Biochemistry of the dental plaque. Advances in Oral Biology 4:43-90

Kodaka T, Debari K, Higashi S (1988) Magnesium-containing crystals in human dental calculus. Microsc 37:73-80 https://doi.org/10.1093/oxfordjournals,jmicro.a050666

Koutsopoulos S (2002) Synthesis and characterization of hydroxyapatite crystals: a review study on the analytical methods. Journal of Biomedical Materials Research Part A: An Official Journal of The Society for Biomaterials, The Japanese Society for Biomaterials, and The Australian Society for Biomaterials and the Korean Society for Biomaterials 62:600-612

Lalueza-Fox C, Juan J, Albert RM (1996) Phytolith analysis on dental calculus, enamel surface and burial soil: information about diet and paleoenvironment. Am J Phys Anthropol 101:101-113

Laurence AR, Thoms AV, Bryant VM, McDonough C (2011) Airborne starch granules as a potential contamination source at archaeological sites. J Ethnobiol 31:213-232 https://doi.org/10.2993/0278-0771-31.2.213

Li M, Yang Z, Wang H, Wang Q, Jia X, Ge QS (2010) Starch grains from dental calculus reveal ancient plant foodstuffs at Chenqimogou site, Gansu Province. Sci China Earth Sci 53:694699 https://doi.org/10.1007/s11430-010-0052-9

Madella M, García-Granero JJ, Out WA, Ryan P, Usai D (2014) Microbotanical evidence of domestic cereals in Africa 7000 years ago. PLoS One 9:e110177 https://doi.org/10.1371/journal.pone.0110177

Maher GG (1983) Alkali gelatinization of flours. Starch-Stärke 35:271-276

Mathlouthi M, Koenig JL (1987) Vibrational spectra of carbohydrates. Adv Carbohydr Chem Biochem 44:7-89 
Mercader J (2002) Forest people: the role of African rainforests in human evolution and dispersal. Evol Anthropol 11:117-124

Mercader J, Abtosway M, Baquedano E, William Bird RW, Diez-Martin F, Domínguez-Rodrigo M, Favreau J, Itambu M, Lee P, Mabulla A, Patalano R, Pérez-González A, Santonja M, Tucker L, Walde D (2017) Starch contamination landscapes in field archaeology: Olduvai Gorge, Tanzania. Boreas 46:918-934 https://doi.org/10.1111/bor.12241. ISSN 0300-9483

Mercader J, Akeju T, Brown M, Bundala M, Collins MJ, Copeland L, Crowther A, Dunfield P, Henry A, Inwood J, Itambu I, Kim J-J, Larter S, Longo L, Oldenburg T, Patalano R, Sammynaiken R, Soto M, Tyler R, Xhauflair H (2018) Exaggerated expectations in ancient starch research and the need for new taphonomic and authenticity criteria. Facets 30:777798 https://doi.org/10.1139/facets-2017-0126

Mercader J, Garralda MD, Pearson O, Bailey R (2001) 800 year old human remains from the Ituri tropical forest, Democratic Republic of Congo: the rock shelter site of Matangai Turu NW. Am J Phys Anthropol 115:24-37

Mercader J, Runge F, Vrydaghs L, Doutrelepont H, Ewango CEN, Juan-Tresseras J (2000) Phytoliths from Archaeological Sites in the Tropical Forest of Ituri, Democratic Republic of Congo. Quat Res 54:102-112

Mickelburgh HL, Pagan-Jimenez JR (2012) New insights into the consumption of maize and other food plants in the pre-columbian Caribbean from starch granules trapped in human dental calculus. J Archaeol Sci 39:2468-2478 https://doi.org/10.1016/j.jas.2012.02.020

Middleton WD, Rovner I (1994) Extraction of opal phytoliths from herbivore dental calculus. J Archaeol Sci 32:469-473 https://doi.org/10.1006/jasc.1994.1046

Osman MO, Jensen SL (1999) Surgical gloves: current probelms. World J Surg 23:630-637 https://doi.org/10.1007/PL00012360

Otsuka M, Moritaka H, Fukuba H, Kimura S, Ishihara M (2001) Effects of calcium carbonate and calcium hydroxide on gelatinization and retrodegradation of corn starch. J Japan Soc Food Sci Technol 48:751-758 https://doi.org/10.3136/nskkk.48.751

Pedergnana A, Asryan L, Fernández-Marchena JL, Ollé A (2016) Modern contaminants affecting microscopic residue analysis on stone tools: a word of caution. Micron 86:1-21 https://doi.org/10.1016/j.micron.2016.04.003

Pérez S, Baldwin PM, Gallant DJ (2009) Structural features of starch granules I. In: BeMiller J, Whistler R (eds) Starch: Chemistry and Technology. 3rd edn. Academic Press, Burlington, pp 149-192. doi:10.1016/B978-0-12-746275-2.00005-7

Perez S, Bertoft E (2010) The molecular structures of starch components and their contribution to the architecture of starch granules: a comprenhesive review. Starch-Stärke 62:389-420

Piperno DR, Dillehay TD (2008) Starch grains on human teeth reveal broad crop diet in northern Peru. Proc Natl Acad Sci 105:19622-19627 https://doi.org/10.1073/pnas.0808752105

Power RC, Salazar-García DC, Henry AG (2016) Dental calculus evidence of Gravettian diet and behavior at Dolni Vestonice and Pavlov. In: Svoboda JA (ed) Dolní Věstonice II: Chronostratigraphy, Paleoethnology, Paleoanthropology. Academy of Sciences of the Czech Republic, Institute of Archeology, Brno, pp 345-352

Power RC, Salazar-García DC, Rubini M, Darlas A, Havarti K, Walker MJ, Hublin JJ, Henry AG (2018) Dental calculus indicates widespread plant use within the stable Neanderthal dietary niche. J Hum Evol 119:27-41 https://doi.org/10.1016/j.jhevol.2018.02.009

Power RC, Salazar-García DC, Straus LG, Morales MRG, Henry AG (2015) Microremains from El Mirón Cave human dental calculus suggests a mixed plant-animal subsistence economy 
furing the Magdalenian in Northern Iberia. J Archaeol Sci 60:39-46 https://doi.org/10.1016/j.jas.2015.04.003

Power RC, Salazar-García DC, Wittig RM, Henry AG (2014) Assessing use and suitability of scanning electron microscopy in the analysis of micro remains in dental calculus. $\mathrm{J}$ Archaeol Sci 49:160-169 https://doi.org/10.1016/j.jas.2014.04.016

Ragheb AA, Abd El-Thalouth I, Tawfik S (1995) Gelatinization of starch in aqueous alkaline solutions. Starch - Stärke 47:338-345

Rizzo AA, Scott DB, Bladen HA (1963) Calcification of oral bacteria. Ann NY Acad Sci 109:1422 https://doi.org/10.1111/j.1749-6632.1963.tb13458.x

Rodríguez A, Allue E, Buxó R (2016) Agriculture and livestock economy among prehistoric herders based on plant macro-remains from El Mirador (Atapuerca, Burgos). Quatern Int 414:272-284 https://doi.org/10.1016/j.quaint.2016.01.045

Rosan B, Lamont RJ (2000) Dental plaque formation. Microbes Infect 2:1599-1607 https://doi.org/10.1016/s1286-4579(00)01316-2

Rowles SL (1964) Biophysical studies on dental calculus in relation to periodontal disease. Dent Pract Dent Rec 15:2-7

Schofield PF, Knight KS, van der Houwen JAM, Valsami-Jones E (2004) The role of hydrogen bonding in the thermal expansion and dehydration of brushite, di-calcium phosphate dihydrate. Phys Chem Min 31:606-624

Schroeder HE, Bambauer HU (1966) Stages of calcium phosphate crystallisation during calculus formation. Arch Oral Biol 11:1-14 https://doi.org/10.1016/0003-9969(66)90112-9

Schroeder LW, Dickens B, Brown WE (1977) Crystallographic studies of the role of Mg as a stabilizing impurity in ß-Ca3 (PO4)2. II. Refinement of Mg-containing ß-Ca3(PO4)2. J Solid State Chem 22:253-262

Sudarsanan K, Young RA (1969) Significant precision in crystal structural details: Holly Springs hydroxyapatite. Acta Cryst 25:1534-1543 https://doi.org/10.1107/S0567740869004298

Swanson MC, Ramalingam M (2002) Starch and natural rubber allergen interaction in the production of latex gloves: a hand-held aerosol. J Allergy Clin Immunol 110:S15-S20 https://doi.org/10.1067/mai.2002.125338

Swärdstedt T (1966) Odontological aspects of a Medieval population in the province of Jämtland, mid-Sweden. University of Lund,

Tao D, Zhang J, Zheng W, Cao Y, Sun K, Jin S (2015) Starch grain analysis of human dental calculus to investigate Neolithic consumption of plants in the middle Yellow River Valley, China: a case study on Gouwan site. J Archaeol Sci Rep 2:485-491 https://doi.org/10.1016/j.jasrep.2015.05.003

Tas AC (2016) Transformation of brushite (CaHPO4.2H2O) to whitlockite (Ca9Mg (HPO4)(PO4)6) or other CaPs in physiologically relevant solutions. J Am Ceram Soc 99:1200-1206

Tavarone A, de los Milagros Colobig M, Passeggi E, Fabra M (2018) Cleaning protocol of archaeological dental calculus: a methodological proposal for vegetable microremains analysis. Am J Phys Anthropol 167 https://doi.org/10.1002/ajpa.23630

Tromp M, Buckley H, Geber J, Matisoo-Smith E (2017) EDTA decalcification of dental calculus as an alternate means of microparticle extraction from archaeological samples. J Archaeol Sci Rep 14:461-466 https://doi.org/10.1016/j.jasrep.2017.06.035 
Tromp M, Dudgeon JV (2015) Differentiating dietary and non-dietary microfossils extracted from human dental calculus: the importance of sweet potato to ancient diet on Rapa Nui. J Archaeol Sci 54:54-63 https://doi.org/10.1016/j.jas.2014.11.024

Tsuda H, Arends J (1993) Raman spectra of human dental calculus. J Dent Res 72:1609-1613

Vergès JM, Alluè E, Fontanals M, Morales JI, Martín P, Carrancho Á, Expósito I, Guardiola M, Lozano M, Marsal R, Oms X, Euba I, Rodríguez A (2016) El Mirador cave (Sierra de Atapuerca, Burgos, Spain): a whole perspective. Quatern Int 414:236-243 https://doi.org/10.1016/j.quaint.2016.01.044

Wang Y-J, Wang L (2002) Characterization of acetylated waxy maize starches prepared under catalysis by different alkali and alkaline-earth hydroxides. Starch-Stärke 54:25-30

Warinner C, Hendy J, Speller C, Cappellini E, Fischer R, Trachsel R, Arneborg J, Lynnerup N, Craig OE, Swallow DM, Fotakis A, Christensen RJ, Olsen JV, Liebert A, Montalva N, Fiddyment S, Charlton S, Mackie M, Canci A, Bouwman A, Ruhi F, Gilbert MTP, Collins M (2014) Direct evidence of milk consumption from ancient human dental calculus. Nature Scientific Reports 4:1-6

Warinner C, Herbig A, Mann A, Fellows Yates JA, Weiß CL, Burbano HA, Orlando L, LKrause $\mathrm{J}$ (2017) A robust framework for microbial archaeology. Ann Rev Genomics Hum Genet 18:321-356 https://doi.org/10.1146/annurev-genom-091416-035526

Warinner C, Speller C, Collins MJ (2015) A new era in palaeomicrobiology: prospects for ancient dental calculus as a long-term record of the human oral microbiome. Philosophical Transactions of the Royal Society B 370:20130376 https://doi.org/10.1098/rstb.2013.0376

Wesolowski V, de Souza SMFM, Reinhard KJ, Ceccantini G (2010) Evaluating microfossil content of dental calculus from Brazilian sambaquis. J Archaeol Sci 37:1326-1338

Weyrich LS, Dobney K, Cooper A (2015) Ancient DNA analysis of dental calculus. J Hum Evol 79:119-124 https://doi.org/10.1016/j.jhevol.2014.06.018

Weyrich LS, Duchene S, Soubrier J, Arriola L, Llamas B, Breen J, Morris AG, Alt KW, Caramelli D, Dresely V, Farrell M, Farrer AG, Francken M, Gully M, Haak W, Hardy K, Harvati K, Held P, Holmes EC, Kaidonis J, Lalueza-Fox C, de la Rasilla M, Rosas A, Semal P, Soltysiak A, Townsend G, Usai D, Wahl J, Huson DH, Dobney K, Cooper A (2017) Neanderthal behavior, diet, and disease inferred from ancient DNA in dental calculus. Nature 544:357-372

Whittam MA, Noel TR, Ring SG (1990) Melting behaviour of A- and B-type crystalline starch. Int J Biol Macromol 12:359-362 https://doi.org/10.1016/0141-8130(90)90043-A

Wolstenholme GEW, O'Connor M (2009) Caries-Resistant Teeth vol 964. John Wiley and Sons,

Yamada T, Morimoto Y, Hisamatsu M (1986) Effect of citric acid on potato starch gelatinization. Starch-Stärke 38:264-268

Zhang B, Dhital S, Flanagan BM, Gidley MJ (2014) Mechanism for starch granule ghost formation deduced from structural and enzyme digestion properties. J Agric Food Chem 62:760-771 https://doi.org/10.1021/jf404697v 
Table 1 Parameters used in the production of calculus

Table 2 XPS elemental breakdown

Table 3 High resolution XPS results and fitting

Table 4 Diffraction peaks for brushite, hydroxyapatite, whitlockite, and octacalcium phosphate

Table 5 Degradation effects of decontamination admixtures on potato and corn starch granules

Fig. 1 Dental sample from El Mirador: a) calculus in-situ, b-n) exogenous starch granules, o) calculus decontaminated after immersion in sodium hydroxide, p-u) exogenous phytoliths

Fig. 2 Dental sample from Matangai Turu NW: a) calculus in-situ, b-aw) exogenous starch granules, ax) calculus decontaminated after immersion in sodium hydroxide, ay) calculus with entrapped starch granules (white arrows) az-bc) exogenous phytoliths

Fig. 3 Raman spectra for synthetic and archeological dental calculus from El Mirador and Matangai Turu NW

Fig. 4 Raman peaks for synthetic and dental calculus (full width at half maximum)

Fig. 5 Comparison of Raman luminescence spectral profiles for dental calculus and synthetic samples

Fig. 6 XPS survey spectra for dental and synthetic calculus: a) El Mirador, b) Matangai Turu NW, c) 6.85 , d) 6.84

Fig. 7 XPS spectra for carbon (C1s): a) El Mirador, b) Matangai Turu NW, c) 6.85, d) 6.84

Fig. 8 XPS spectra for oxygen (O1s): a) El Mirador R, b) Matangai Turu NW, c) 6.85, d) 6.84

Fig. 9 XPS spectra for calcium phosphate (Ca2p): a) El Mirador, b) Matangai Turu NW, c) 6.85, d) 6.84

Fig. 10 XPS spectra for phosphorus: a) El Mirador, b) Matangai Turu NW, c) 6.85, d) 6.84

Fig. 11 P-XRD patterns of synthetic and dental calculus: a) sample 6.84, b) sample 6.85, c) MTNW, d) El Mirador

Fig. 12 P-XRD fitting for synthetic and dental calculus: a) El Mirador [i, XRD pattern; ii, fitting; iii, difference], b) Matangai Turu NW [i, XRD pattern; ii, fitting; iii, difference], c) synthetic sample 6.85 [i, XRD pattern; ii, fitting; iii, difference], d) synthetic sample 6.84 [i, XRD pattern; ii, fitting; iii, difference]

Fig. 13 Experimental contamination: a) corn granules (orange arrows) are pervasively adsorbed onto the surface, and also b) infilling crevices. Note the underlying calcium phosphate matrix with potato starch granules (white arrows)

Fig. 14 Effect of calcium hydroxide on potato starch granules

Fig. 15 Effect of calcium hydroxide on corn starch granules 
Fig. 16 Effect of EDTA on potato starch granules

Fig. 17 Effect of EDTA on corn starch granules

Fig. 18 Effect of $\alpha$-amylase on potato starch granules

Fig. 19 Effect of $\alpha$-amylase on corn starch granules

Fig. 20 Effects of decontamination protocol proposed in this paper: a) before: synthetic matrix with embedded potato granules (white arrows) contaminated with corn granules (orange arrows), b) after: potato starch granules have remained trapped (white arrows) while corn starch granules have gelatinized and leached beyond detection by optical microscopy

Fig. 21 a-c) Calcium phosphate casts coated potato starch granules from synthetic calculus: Notice how the granule areas without the protection of a cast (white arrows) gelatinize (Fig 21 a,b: cross-polarized images). Fig. 21 e-f shows phosphate crystallizations along the edges of the synthetic matrix and discrete granules, g-j) Calculus permeation by iodine: co-precipitated potato starch granules stained purple and confirmed retention of biochemical functionality, original size, crystallite arrangement, native birefringence, Maltese cross, and lamellae

Fig. 22 Effects of experimental cleaning of calculus with a dry toothbrush: a) corn granules coat most of the synthetic matrix (before brushing, one minute), b) incomplete elimination of contaminant granules (remaining granules, $\mathrm{n}=164$ ), c) corn starch coats the synthetic matrix (before brushing five minutes), d) the elimination of contaminant granules is partial (granules remaining, $\mathrm{n}=334$ ) 
Table 1

\begin{tabular}{|c|c|c|c|c|c|c|c|c|}
\hline $\begin{array}{l}\text { Calcium } \\
\text { carbonate } \\
\text { (g) }\end{array}$ & $\begin{array}{c}\text { Calcium } \\
\text { chloride } \\
(w / v)\end{array}$ & $\begin{array}{l}\text { Starch } \\
(w / v)\end{array}$ & $\begin{array}{l}\text { Glycine } \\
\text { added }\end{array}$ & $\begin{array}{c}\text { Ammonium } \\
\text { phosphate } \\
(w / v)\end{array}$ & $\begin{array}{c}\text { Amount of } \\
\text { Sodium hydroxide } \\
(0.05) \text { added (ml) }\end{array}$ & $\begin{array}{c}\mathbf{p H} \\
\text { (Solution) }\end{array}$ & $\begin{array}{c}\mathbf{p H} \\
\text { (Precipitation) }\end{array}$ & $\begin{array}{c}\text { Final } \\
\text { weight } \\
\text { (g) }\end{array}$ \\
\hline 2.64 & 0.001 & 0.001 & $\mathrm{Y}$ & 0.01 & N/A & 6.30 & 6.30 & 2.75 \\
\hline 4.28 & 0.001 & 0.001 & $\mathrm{~N}$ & 0.1 & N/A & 6.02 & 6.02 & 5.09 \\
\hline 2.84 & 0.01 & 0.01 & $\mathrm{~N}$ & 0.1 & $>20.00$ & 7.37 & 8.35 & 8.94 \\
\hline 2.06 & 0.01 & 0.01 & $\mathrm{~N}$ & 0.1 & 0.70 & 6.11 & 6.11 & 2.73 \\
\hline 2.72 & 0.02 & 0.02 & $\mathrm{~N}$ & 0.02 & 3.00 & 5.47 & 6.11 & 2.78 \\
\hline 3.83 & 0.02 & 0.02 & Y & 0.02 & 0.01 & 6.29 & 6.92 & 3.93 \\
\hline 5.81 & 0.05 & 0.05 & $\mathrm{~N}$ & 0.05 & N/A & 6.40 & 7.00 & 5.89 \\
\hline 5.42 & 0.05 & 0.05 & $\mathrm{Y}$ & 0.05 & 0.13 & 6.80 & 7.00 & 5.49 \\
\hline 7.66 & 0.05 & 0.05 & $\mathrm{Y}$ & 0.05 & 0.60 & 7.99 & 6.80 & 8.36 \\
\hline 9.58 & 0.05 & 0.05 & $\mathrm{Y}$ & 0.05 & 0.60 & 7.04 & 7.11 & 9.94 \\
\hline 7.02 & 0.05 & 0.05 & $\mathrm{Y}$ & 0.05 & 0.90 & 7.21 & 6.75 & 7.20 \\
\hline 9.48 & 0.05 & 0.05 & $\mathrm{Y}$ & 0.05 & 0.60 & 6.64 & 6.65 & 9.65 \\
\hline 7.52 & 0.05 & 0.05 & $\mathrm{Y}$ & 0.05 & 0.60 & 6.40 & 6.69 & 7.65 \\
\hline 4.01 & 0.05 & 0.05 & $\mathrm{Y}$ & 0.05 & 3.50 & 6.94 & 7.00 & 4.40 \\
\hline 6.85 & 0.05 & 0.05 & $\mathrm{Y}$ & 0.05 & 3.00 & 6.25 & 7.00 & 7.89 \\
\hline 6.84 & 0.05 & 0.05 & $Y$ & 0.05 & 3.55 & 6.59 & 7.30 & 8.05 \\
\hline 3.61 & 0.05 & 0.05 & $\mathrm{Y}$ & 0.05 & 3.50 & 6.50 & 7.00 & 4.16 \\
\hline 9.17 & 0.05 & 0.05 & $Y$ & 0.05 & 2.50 & 6.73 & 7.00 & 10.36 \\
\hline 5.19 & 0.05 & 0.05 & $\mathrm{Y}$ & 0.05 & 2.75 & 7.20 & 7.00 & 6.81 \\
\hline 3.88 & 0.10 & 0.10 & $\mathrm{Y}$ & 0.10 & 0.31 & 7.00 & 6.47 & 4.78 \\
\hline 4.65 & 0.10 & 0.10 & $\mathrm{Y}$ & 0.10 & 0.31 & 7.00 & 6.84 & 4.84 \\
\hline 4.09 & 0.10 & 0.10 & $\mathrm{Y}$ & 0.10 & 1.31 & 5.69 & 7.04 & 4.25 \\
\hline 4.09 & 0.10 & 0.10 & $\mathrm{Y}$ & 0.10 & 0.31 & 7.00 & 6.63 & 4.24 \\
\hline 4.09 & 0.10 & 0.10 & $\mathrm{Y}$ & 0.10 & 0.31 & 7.00 & 6.27 & 4.50 \\
\hline 3.72 & 0.10 & 0.10 & $\mathrm{Y}$ & 0.10 & 1.00 & 6.45 & 6.45 & 3.96 \\
\hline 2.80 & 0.10 & 0.10 & $\mathrm{Y}$ & 0.10 & N/A & 6.91 & 6.91 & 3.39 \\
\hline
\end{tabular}


Table 2

\begin{tabular}{|c|c|c|c|c|}
\hline Element & $\begin{array}{c}\text { ATA10MIR } \\
(\%)\end{array}$ & $\begin{array}{c}\text { MTWN } \\
(\%)\end{array}$ & $\begin{array}{c}\text { Synthetic } 6.84 \\
\text { (\%) }\end{array}$ & $\begin{array}{c}\text { Synthetic } 6.85 \\
(\%)\end{array}$ \\
\hline C1s & 19.3 & 58.4 & 13.6 & 37.1 \\
\hline O1s & 45.4 & 21.7 & 53.1 & 17.6 \\
\hline $\mathrm{Ca} 2 \mathrm{p}$ & 14.1 & 10.2 & 14.2 & 2.8 \\
\hline $\mathrm{P} 2 \mathrm{p}$ & 6.8 & 6.1 & 13.4 & 2.8 \\
\hline N1s & 0.8 & 0.9 & 3.7 & 15.6 \\
\hline Si2p & 10.7 & 1.3 & N/A & N/A \\
\hline $\mathrm{Al} 2 \mathrm{p}$ & 1.6 & 1.5 & N/A & N/A \\
\hline $\mathrm{Cl} 2 \mathrm{p}$ & N/A & $\mathrm{N} / \mathrm{A}$ & 1.8 & 20.7 \\
\hline $\mathrm{Na} 1 \mathrm{~s}$ & N/A & N/A & 0.2 & 3.0 \\
\hline $\mathrm{s} 2 \mathrm{p}$ & N/A & N/A & N/A & 0.5 \\
\hline
\end{tabular}


Table 3

\begin{tabular}{|c|c|c|c|c|c|c|c|c|c|c|c|c|}
\hline \multirow[b]{2}{*}{ Sample } & \multicolumn{3}{|c|}{ C1s } & \multicolumn{3}{|c|}{ O1s } & \multicolumn{3}{|c|}{ Ca2p } & \multicolumn{3}{|c|}{ P2p } \\
\hline & $\begin{array}{l}\text { Energy } \\
(\mathrm{eV})\end{array}$ & Assignment & $\begin{array}{c}\text { Percentage } \\
\text { (\%) }\end{array}$ & $\begin{array}{c}\text { Energy } \\
(\mathrm{eV})\end{array}$ & Assignment & $\begin{array}{c}\text { Percentage } \\
\text { (\%) }\end{array}$ & $\begin{array}{c}\text { Energy } \\
(\mathrm{eV})\end{array}$ & Assignment & $\begin{array}{l}\text { Percentage } \\
\text { (\%) }\end{array}$ & $\begin{array}{c}\text { Energy } \\
(\mathrm{eV})\end{array}$ & Assignment & $\begin{array}{c}\text { Percentage } \\
(\%)\end{array}$ \\
\hline \multirow{4}{*}{ ATA10MIR } & 284.8 & $\mathrm{C}-\mathrm{C} / \mathrm{CH}$ & 63.3 & 531.6 & $\mathrm{Ca}_{\mathrm{x}}\left(\mathrm{PO}_{4}\right)_{\mathrm{y}}, \mathrm{COH}$ & 63.6 & 347.5 & $\mathrm{Ca}_{\mathrm{x}}\left(\mathrm{PO}_{4}\right)_{\mathrm{y}}$ & 67.2 & 133.3 & $\mathrm{Ca}_{\mathrm{x}}\left(\mathrm{PO}_{4}\right)_{\mathrm{y}}$ & 66.7 \\
\hline & 286.1 & $\mathrm{COC} / \mathrm{CN}$ & 26.1 & 532.5 & $\mathrm{COOH} / \mathrm{COC} / \mathrm{SiOx}$ & 36.4 & 351.1 & $\mathrm{Ca}_{\mathrm{x}}\left(\mathrm{PO}_{4}\right)_{\mathrm{y}}$ & 32.8 & 134.1 & $\mathrm{Ca}_{x}\left(\mathrm{PO}_{4}\right)_{y}$ & 33.3 \\
\hline & 288.7 & $\mathrm{COOH}$ & 8.8 & & & & & & & & & \\
\hline & 290.2 & $\mathrm{CO}_{3}$ & 1.8 & & & & & & & & & \\
\hline \multirow{5}{*}{ MTWN } & 284.6 & $\mathrm{C}-\mathrm{C} / \mathrm{CH}$ & 46.1 & 531.4 & $\mathrm{Ca}_{\mathrm{x}}\left(\mathrm{PO}_{4}\right)_{\mathrm{y}}, \mathrm{COH}$ & 67.2 & 347.4 & $\mathrm{Ca}_{\mathrm{x}}\left(\mathrm{PO}_{4}\right)_{\mathrm{y}}$ & 67.1 & 133.1 & $\mathrm{Ca}_{\mathrm{x}}\left(\mathrm{PO}_{4}\right)_{\mathrm{y}}$ & 66.7 \\
\hline & 285.3 & $\mathrm{COH}$ & 16.1 & 533.0 & $\mathrm{COOH} / \mathrm{COC} / \mathrm{SiOx}$ & 32.8 & 350.9 & $\mathrm{Ca}_{\mathrm{x}}\left(\mathrm{PO}_{4}\right)_{\mathrm{y}}$ & 32.9 & 133.9 & $\mathrm{Ca}_{\mathrm{x}}\left(\mathrm{PO}_{4}\right)_{\mathrm{y}}$ & 33.3 \\
\hline & 286.3 & $\mathrm{COC} / \mathrm{CN}$ & 18.9 & & & & & & & & & \\
\hline & 287.2 & $\mathrm{CO}$ & 6.4 & & & & & & & & & \\
\hline & 288.5 & $\mathrm{COOH}$ & 12.4 & & & & & & & & & \\
\hline \multirow{3}{*}{$\begin{array}{c}\text { Synthetic } \\
6.84\end{array}$} & 284.7 & $\mathrm{C}-\mathrm{C} / \mathrm{CH}$ & 21.2 & 530.8 & $\mathrm{Ca}_{\mathrm{x}}\left(\mathrm{PO}_{4}\right)_{\mathrm{y}}, \mathrm{COH}$ & 65.9 & 347.1 & $\mathrm{Ca}_{\mathrm{x}}\left(\mathrm{PO}_{4}\right)_{\mathrm{y}}$ & 67.9 & 132.9 & $\mathrm{Ca}_{\mathrm{x}}\left(\mathrm{PO}_{4}\right)_{\mathrm{y}}$ & 66.7 \\
\hline & 286.1 & $\mathrm{COC} / \mathrm{CN}$ & 44.1 & 532.4 & $\mathrm{COOH} / \mathrm{COC} / \mathrm{SiOx}$ & 34.1 & 350.6 & $\mathrm{Ca}_{\mathrm{x}}\left(\mathrm{PO}_{4}\right)_{\mathrm{y}}$ & 32.1 & 133.8 & $\mathrm{Ca}_{\mathrm{x}}\left(\mathrm{PO}_{4}\right)_{\mathrm{y}}$ & 33.3 \\
\hline & 288.5 & $\mathrm{COOH}$ & 34.6 & & & & & & & & & \\
\hline \multirow{4}{*}{$\begin{array}{c}\text { Synthetic } \\
6.85\end{array}$} & 284.7 & $\mathrm{C}-\mathrm{C} / \mathrm{CH}$ & 68.0 & 531.1 & $\mathrm{Ca}_{\mathrm{x}}\left(\mathrm{PO}_{4}\right)_{\mathrm{y}}, \mathrm{COH}$ & 61.4 & 347.3 & $\mathrm{Ca}_{\mathrm{x}}\left(\mathrm{PO}_{4}\right)_{\mathrm{y}}$ & 66.9 & 133.1 & $\mathrm{Ca}_{\mathrm{x}}\left(\mathrm{PO}_{4}\right)_{\mathrm{y}}$ & 69.0 \\
\hline & 286.1 & $\mathrm{COC} / \mathrm{CN}$ & 19.9 & 532.6 & $\mathrm{COOH} / \mathrm{COC} / \mathrm{SiOx}$ & 30.5 & 350.9 & $\mathrm{Ca}_{x}\left(\mathrm{PO}_{4}\right)_{\mathrm{y}}$ & 33.1 & 134.0 & $\mathrm{Ca}_{x}\left(\mathrm{PO}_{4}\right)_{\mathrm{y}}$ & 31.0 \\
\hline & 288.5 & $\mathrm{COOH}$ & 11.1 & 536.2 & Na KLL Auger peak & 8.1 & & & & & & \\
\hline & 289.9 & $\mathrm{CO}_{3}$ & 1.0 & & & & & & & & & \\
\hline
\end{tabular}


Table 4

\begin{tabular}{|c|c|c|c|c|c|c|c|c|c|}
\hline \multicolumn{2}{|c|}{ Brushite } & \multicolumn{2}{c|}{ Hydroxyapatite } & \multicolumn{2}{c|}{ Fluorapatite } & \multicolumn{2}{c|}{ Whitlockite } & \multicolumn{2}{c|}{$\begin{array}{c}\text { Octacalcium } \\
\text { Phosphate }\end{array}$} \\
\hline $2 \theta\left(^{\circ}\right)$ & Intensity & $2 \theta\left(^{\circ}\right)$ & Intensity & $2 \theta\left(^{\circ}\right)$ & Intensity & $2 \theta\left(^{\circ}\right)$ & Intensity & $2 \theta\left(^{\circ}\right)$ & Intensity \\
\hline 11.65 & 100.00 & 10.78 & 18.00 & 25.87 & 36.80 & 13.74 & 19.10 & 4.70 & 100.00 \\
20.96 & 94.00 & 25.84 & 36.80 & 28.14 & 11.60 & 17.14 & 30.40 & 9.31 & 8.20 \\
29.31 & 69.10 & 28.88 & 14.80 & 29.10 & 14.80 & 20.40 & 12.30 & 9.70 & 7.90 \\
30.55 & 47.10 & 31.73 & 100.00 & 31.92 & 100.00 & 22.04 & 10.10 & 24.17 & 6.40 \\
34.19 & 38.30 & 32.16 & 46.40 & 32.242 & 38.80 & 25.10 & 27.30 & 25.92 & 9.00 \\
34.44 & 25.30 & 32.86 & 61.20 & 33.09 & 57.40 & 28.05 & 49.50 & 31.28 & 8.00 \\
36.93 & 13.30 & 34.03 & 23.40 & 34.13 & 26.60 & 29.92 & 13.00 & 33.37 & 5.30 \\
37.14 & 12.80 & 39.76 & 21.20 & 40.02 & 21.90 & 31.31 & 100.00 & & \\
41.60 & 18.20 & 46.67 & 29.90 & 46.86 & 28.50 & 32.75 & 17.50 & & \\
42.08 & 16.10 & 48.06 & 12.90 & 48.25 & 13.30 & 34.68 & 65.20 & & \\
48.53 & 15.00 & 49.47 & 32.60 & 49.54 & 35.10 & 35.91 & 13.70 & & \\
50.20 & 12.00 & 50.46 & 17.40 & 50.74 & 16.40 & 41.47 & 11.30 & & \\
50.27 & 13.20 & 51.24 & 11.80 & 51.55 & 13.70 & 42.07 & 15.70 & & \\
& & 52.06 & 12.10 & 52.27 & 13.70 & 47.41 & 22.20 & & \\
& & 53.20 & 14.80 & 53.14 & 16.90 & 48.44 & 17.40 & & \\
& & & & & & 48.86 & 14.10 & & \\
& & & & & & 53.47 & 26.90 & & \\
\hline
\end{tabular}


Table 5

\begin{tabular}{|c|c|c|c|c|c|c|c|c|}
\hline Potato & $\begin{array}{c}\text { Amylase } \\
(w / v)\end{array}$ & Effects & EDTA (w/v) & Effects & $\begin{array}{l}\text { Calcium } \\
\text { hydroxide } \\
\text { (w/v) }\end{array}$ & Effects & $\begin{array}{c}\text { Sodium } \\
\text { hydroxide } \\
\text { (w/v) }\end{array}$ & Effects \\
\hline T0 & 0.001 & $\begin{array}{l}\text { Radial fissuring/ } \\
\text { Birefringence } \\
\text { loss/Disarticulati } \\
\text { on }\end{array}$ & $\begin{array}{c}0.001+ \\
(\mathrm{NaOH} 1 \mathrm{ml})\end{array}$ & $\begin{array}{l}\text { None observed/ } \\
\text { Radial fissuring }\end{array}$ & 0.01 & $\begin{array}{l}\text { None observed/ } \\
\text { Clefting/ } \\
\text { Implosion }\end{array}$ & 0.001 & $\begin{array}{l}\text { Gelatinization/ } \\
\text { Birefringence } \\
\text { loss/ } \\
\text { Disarticulation }\end{array}$ \\
\hline T0 & 0.01 & $\begin{array}{l}\text { Clefting/ radial } \\
\text { fissuring/ } \\
\text { Gelatinization/ } \\
\text { Birefringence } \\
\text { loss/ } \\
\text { Disarticulation }\end{array}$ & $\begin{array}{c}0.01+ \\
(\mathrm{NaOH} \\
0.06 \mathrm{~g})\end{array}$ & $\begin{array}{l}\text { None observed/ } \\
\text { Birefringence } \\
\text { loss/ } \\
\text { Disarticulation }\end{array}$ & 0.02 & $\begin{array}{l}\text { None observed/ } \\
\text { Clefting/ } \\
\text { Implosion/ } \\
\text { Disarticulation }\end{array}$ & 0.01 & $\begin{array}{c}\text { Gelatinization/ } \\
\text { Birefringence } \\
\text { loss/ } \\
\text { Disarticulation }\end{array}$ \\
\hline T0 & 0.02 & $\begin{array}{l}\text { Clefting/radial } \\
\text { fissuring/ } \\
\text { Disarticulation }\end{array}$ & $\begin{array}{c}0.02+ \\
(\mathrm{NaOH} \\
0.15 \mathrm{~g})\end{array}$ & $\begin{array}{l}\text { None observed/ } \\
\text { Implosion/ } \\
\text { Gelatinization }\end{array}$ & 0.05 & $\begin{array}{l}\text { None observed/ } \\
\text { Clefting }\end{array}$ & 0.02 & $\begin{array}{l}\text { Birefringence } \\
\text { loss/ Leachate }\end{array}$ \\
\hline T1hr & 0.001 & $\begin{array}{l}\text { Radial fissuring/ } \\
\text { Birefringence } \\
\text { loss }\end{array}$ & $\begin{array}{c}0.001+ \\
(\mathrm{NaOH} 1 \mathrm{ml})\end{array}$ & None observed & 0.01 & $\begin{array}{l}\text { None observed/ } \\
\text { Implosion }\end{array}$ & & \\
\hline T1hr & 0.01 & $\begin{array}{l}\text { Radial fissuring/ } \\
\text { Implosion/ } \\
\text { Birefringence } \\
\text { loss/Disarticulati } \\
\text { on }\end{array}$ & $\begin{array}{c}0.01+ \\
(\mathrm{NaOH} \\
0.06 \mathrm{~g})\end{array}$ & $\begin{array}{l}\text { None observed/ } \\
\text { Birefringence } \\
\text { loss/Gelatinizatio } \\
\text { n/ Disarticulation }\end{array}$ & 0.02 & $\begin{array}{l}\text { None observed/ } \\
\text { Implosion/ } \\
\text { Gelatinization }\end{array}$ & & \\
\hline T1hr & 0.02 & $\begin{array}{l}\text { Radial fissuring/ } \\
\text { Birefringence } \\
\text { loss }\end{array}$ & $\begin{array}{c}0.02+ \\
(\mathrm{NaOH} \\
0.15 \mathrm{~g})\end{array}$ & $\begin{array}{l}\text { None observed/ } \\
\text { Radial } \\
\text { fissuring/Birefrin } \\
\text { gence loss/ } \\
\text { Gelatinization/ } \\
\text { Disarticulation }\end{array}$ & 0.05 & None observed & & \\
\hline T6hr & 0.001 & $\begin{array}{l}\text { Radial fissuring/ } \\
\text { Birefringence } \\
\text { loss/Disarticulati }\end{array}$ & $\begin{array}{c}0.001+ \\
(\mathrm{NaOH} 1 \mathrm{ml})\end{array}$ & $\begin{array}{l}\text { None observed/ } \\
\text { radial fissuring }\end{array}$ & 0.01 & $\begin{array}{l}\text { None observed/ } \\
\text { Implosion }\end{array}$ & & \\
\hline
\end{tabular}




\begin{tabular}{|c|c|c|c|c|c|c|}
\hline T6hr & 0.01 & $\begin{array}{l}\text { Radial fissuring/ } \\
\text { Implosion/ } \\
\text { Birefringence } \\
\text { loss/Disarticulati } \\
\text { on }\end{array}$ & $\begin{array}{c}0.01+ \\
(\mathrm{NaOH} \\
0.06 \mathrm{~g})\end{array}$ & $\begin{array}{l}\text { None observed/ } \\
\text { radial fissuring }\end{array}$ & 0.02 & $\begin{array}{l}\text { None observed/ } \\
\text { Implosion/ } \\
\text { Gelatinization }\end{array}$ \\
\hline T6hr & 0.02 & $\begin{array}{l}\text { Radial fissuring/ } \\
\text { Birefringence } \\
\text { loss/Disarticulati } \\
\text { on }\end{array}$ & $\begin{array}{c}0.02+ \\
(\mathrm{NaOH} \\
0.151 \mathrm{~g})\end{array}$ & None observed & 0.05 & $\begin{array}{l}\text { None observed/ } \\
\text { Radial fissuring }\end{array}$ \\
\hline T24hr & 0.001 & $\begin{array}{l}\text { Radial fissuring/ } \\
\text { Disarticulation }\end{array}$ & $\begin{array}{c}0.001+ \\
(\mathrm{NaOH} 1 \mathrm{ml})\end{array}$ & $\begin{array}{l}\text { None observed/ } \\
\text { radial fissuring/ } \\
\text { Gelatinization }\end{array}$ & 0.01 & $\begin{array}{l}\text { None observed/ } \\
\text { Implosion/ } \\
\text { Birefringence } \\
\text { loss/ } \\
\text { Disarticulation }\end{array}$ \\
\hline T24hr & 0.01 & $\begin{array}{l}\text { Radial fissuring/ } \\
\text { Implosion/ } \\
\text { Disarticulation }\end{array}$ & $\begin{array}{c}0.01+ \\
(\mathrm{NaOH} \\
0.06 \mathrm{~g})\end{array}$ & $\begin{array}{l}\text { None observed/ } \\
\text { radial fissuring }\end{array}$ & 0.02 & $\begin{array}{c}\text { Implosion/ } \\
\text { Birefringence } \\
\text { loss }\end{array}$ \\
\hline $\mathrm{T} 24 \mathrm{hr}$ & 0.02 & $\begin{array}{l}\text { Radial fissuring/ } \\
\text { Implosion/ } \\
\text { Birefringence } \\
\text { loss/ } \\
\text { Disarticulation }\end{array}$ & $\begin{array}{c}0.02+ \\
(\mathrm{NaOH} \\
0.15 \mathrm{~g})\end{array}$ & $\begin{array}{l}\text { None observed/ } \\
\text { radial fissuring/ } \\
\text { Gelatinization/ } \\
\text { Disarticulation }\end{array}$ & 0.05 & $\begin{array}{c}\text { Clefting/ } \\
\text { Implosion/ } \\
\text { Birefringence } \\
\text { loss }\end{array}$ \\
\hline T7d & 0.001 & $\begin{array}{l}\text { Radial fissuring/ } \\
\text { Implosion/ } \\
\text { Birefringence } \\
\text { loss/ } \\
\text { Disarticulation }\end{array}$ & $\begin{array}{c}0.001+ \\
(\mathrm{NaOH} 1 \mathrm{ml})\end{array}$ & None observed & 0.01 & $\begin{array}{l}\text { Gelatinization/ } \\
\text { Implosion/ } \\
\text { Birefringence } \\
\text { loss/ Molecular } \\
\text { ghosts }\end{array}$ \\
\hline T7d & 0.01 & $\begin{array}{l}\text { None observed/ } \\
\text { Implosion/ } \\
\text { Birefringence } \\
\text { loss/ } \\
\text { Disarticulation }\end{array}$ & $\begin{array}{c}0.01+ \\
(\mathrm{NaOH} 0.06 \mathrm{~g} \\
)\end{array}$ & $\begin{array}{l}\text { None observed/ } \\
\text { radial fissuring }\end{array}$ & 0.02 & $\begin{array}{c}\text { Implosion/ } \\
\text { Birefringence } \\
\text { loss/ } \\
\text { Gelatinization }\end{array}$ \\
\hline T7d & 0.02 & $\begin{array}{l}\text { Radial fissuring/ } \\
\text { Birefringence } \\
\text { loss/ } \\
\text { Disarticulation }\end{array}$ & $\begin{array}{c}0.02+ \\
(\mathrm{NaOH} \\
0.15 \mathrm{~g})\end{array}$ & $\begin{array}{l}\text { None observed/ } \\
\text { Radial fissuring }\end{array}$ & 0.05 & $\begin{array}{l}\text { Radial fissuring/ } \\
\text { Implosion/ } \\
\text { Birefringence }\end{array}$ \\
\hline
\end{tabular}


loss/

Disarticulation

\begin{tabular}{|c|c|c|c|c|c|c|}
\hline Corn & $\begin{array}{c}\text { Amylase } \\
(w / v)\end{array}$ & Effects & $\begin{array}{c}\text { EDTA } \\
(w / v)\end{array}$ & Effects & $\begin{array}{c}\text { Calcium } \\
\text { hydroxide } \\
(w / v)\end{array}$ & Effects \\
\hline T0 & 0.001 & None observed & $\begin{array}{c}0.001+ \\
(\mathrm{NaOH} 1 \mathrm{ml})\end{array}$ & None observed & 0.01 & None observed \\
\hline T0 & 0.01 & $\begin{array}{l}\text { None observed/ } \\
\text { Radial fissuring/ } \\
\text { Disarticulation }\end{array}$ & $\begin{array}{c}0.01+ \\
(\mathrm{NaOH} 0.06 \mathrm{~g} \\
)\end{array}$ & None observed & 0.02 & None observed \\
\hline T0 & 0.02 & None observed & $\begin{array}{c}0.02+ \\
(\mathrm{NaOH} \\
0.15 \mathrm{~g})\end{array}$ & None observed & 0.05 & None observed \\
\hline T1hr & 0.001 & $\begin{array}{l}\text { None observed/ } \\
\text { Radial fissuring }\end{array}$ & $\begin{array}{c}0.001+ \\
(\mathrm{NaOH} 1 \mathrm{ml})\end{array}$ & None observed & 0.01 & None observed \\
\hline T1hr & 0.01 & $\begin{array}{c}\text { None } \\
\text { observed/Radial } \\
\text { fissuring/ } \\
\text { Disarticulation }\end{array}$ & $\begin{array}{c}0.01+ \\
(\mathrm{NaOH} 0.06 \mathrm{~g} \\
)\end{array}$ & None observed & 0.02 & $\begin{array}{c}\text { None observed } \\
\text { Gelatinization }\end{array}$ \\
\hline T1hr & 0.02 & $\begin{array}{l}\text { None observed/ } \\
\text { Radial fissuring/ } \\
\text { Disarticulation }\end{array}$ & $\begin{array}{c}0.02+ \\
(\mathrm{NaOH} \\
0.15 \mathrm{~g})\end{array}$ & None observed & 0.05 & None observed \\
\hline T6hr & 0.001 & $\begin{array}{l}\text { None observed/ } \\
\text { Radial fissuring }\end{array}$ & $\begin{array}{c}0.001+ \\
(\mathrm{NaOH} 1 \mathrm{ml})\end{array}$ & None observed & 0.01 & None observed \\
\hline T6hr & 0.01 & $\begin{array}{l}\text { None observed/ } \\
\text { Gelatinization }\end{array}$ & $\begin{array}{c}0.01+ \\
(\mathrm{NaOH} 0.06 \mathrm{~g} \\
)\end{array}$ & None observed & 0.02 & None observed \\
\hline T6hr & 0.02 & $\begin{array}{l}\text { None observed/ } \\
\text { Radial fissuring/ } \\
\text { Disarticulation }\end{array}$ & $\begin{array}{c}0.02+ \\
(\mathrm{NaOH} \\
0.15 \mathrm{~g})\end{array}$ & None observed & 0.05 & None observed \\
\hline $\mathrm{T} 24 \mathrm{hr}$ & 0.001 & $\begin{array}{l}\text { None observed/ } \\
\text { Radial fissuring }\end{array}$ & $\begin{array}{c}0.001+ \\
(\mathrm{NaOH} 1 \mathrm{ml})\end{array}$ & None observed & 0.01 & None observed \\
\hline
\end{tabular}




\begin{tabular}{|c|c|c|c|c|c|c|}
\hline T24hr & 0.01 & $\begin{array}{l}\text { None observed/ } \\
\text { Birefringence } \\
\text { loss/ } \\
\text { Disarticulation }\end{array}$ & $\begin{array}{c}0.01+ \\
(\mathrm{NaOH} 0.06 \mathrm{~g} \\
)\end{array}$ & None observed & 0.02 & None observed \\
\hline T24hr & 0.02 & $\begin{array}{l}\text { None observed/ } \\
\text { Radial fissuring/ } \\
\text { Birefringence } \\
\text { loss/ } \\
\text { Disarticulation }\end{array}$ & $\begin{array}{c}0.02+ \\
(\mathrm{NaOH} \\
0.15 \mathrm{~g})\end{array}$ & None observed & 0.05 & None observed \\
\hline T7d & 0.001 & $\begin{array}{l}\text { None observed/ } \\
\text { Radial fissuring }\end{array}$ & $\begin{array}{c}0.001+ \\
(\mathrm{NaOH} 1 \mathrm{ml})\end{array}$ & None observed & 0.01 & None observed \\
\hline T7d & 0.01 & $\begin{array}{l}\text { None observed/ } \\
\text { Radial fissuring }\end{array}$ & $\begin{array}{c}0.01+ \\
(\mathrm{NaOH} 0.06 \mathrm{~g} \\
)\end{array}$ & None observed & 0.02 & None observed \\
\hline T7d & 0.02 & $\begin{array}{l}\text { None observed/ } \\
\text { Implosion/ } \\
\text { Birefringence } \\
\text { loss/Disarticulati } \\
\text { on }\end{array}$ & $\begin{array}{c}0.02+ \\
(\mathrm{NaOH} \\
0.15 \mathrm{~g})\end{array}$ & None observed & 0.05 & $\begin{array}{l}\text { None observed/ } \\
\text { Disarticulation }\end{array}$ \\
\hline
\end{tabular}




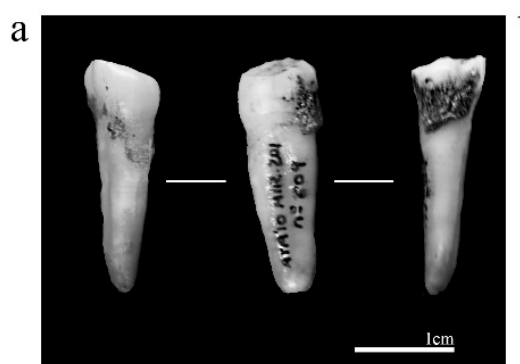

o

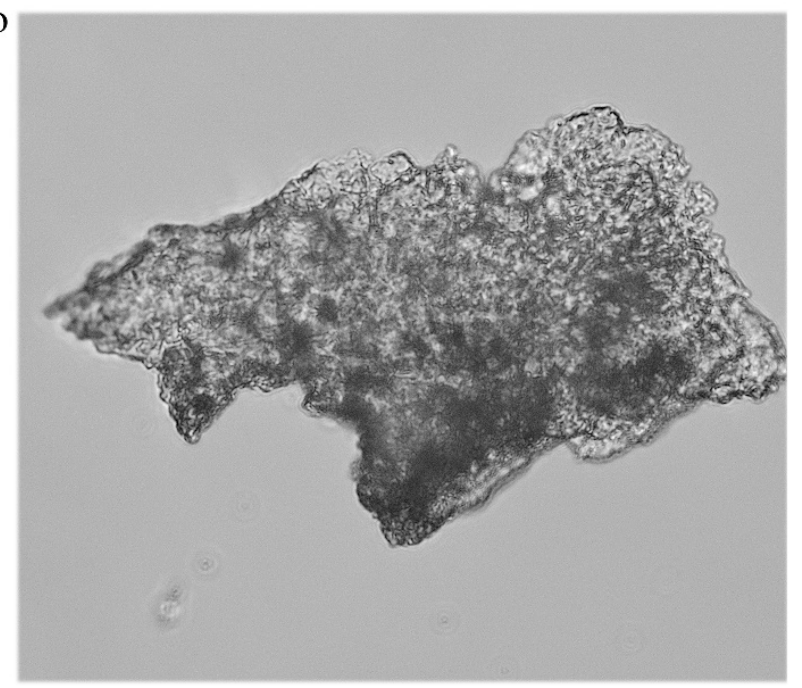

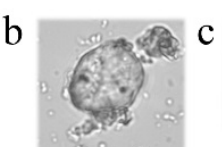

20 व

$d_{0}=e^{2}$

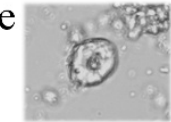

f $0^{80} g$

$k @$

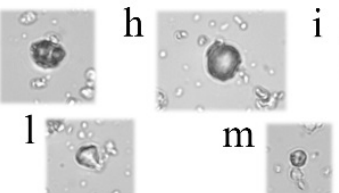

$\mathrm{p}$
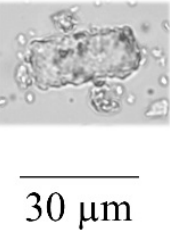

$\mathrm{r}$

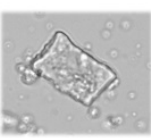

$t$

V

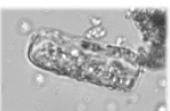

- 8 j

8

q
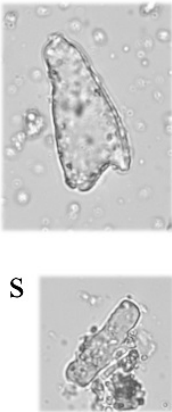

$\mathrm{u}$

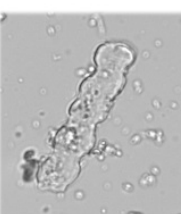

Figure 1 

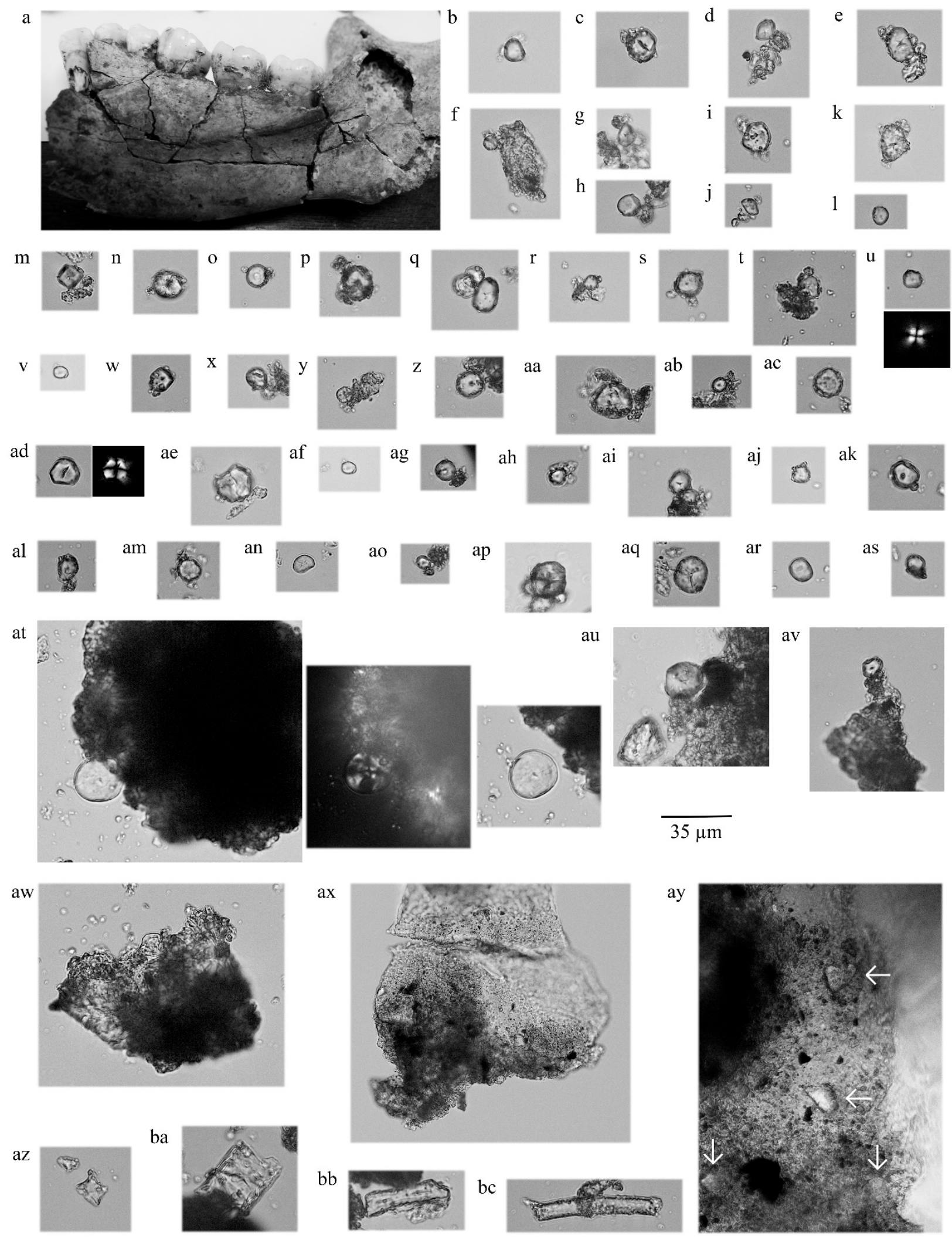

$\mathrm{bb} b \mathrm{sc}$
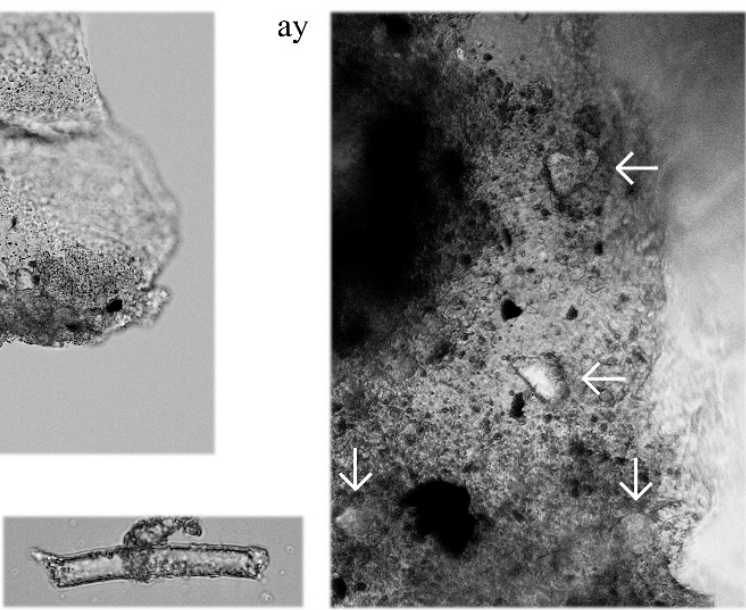

Figure 2 


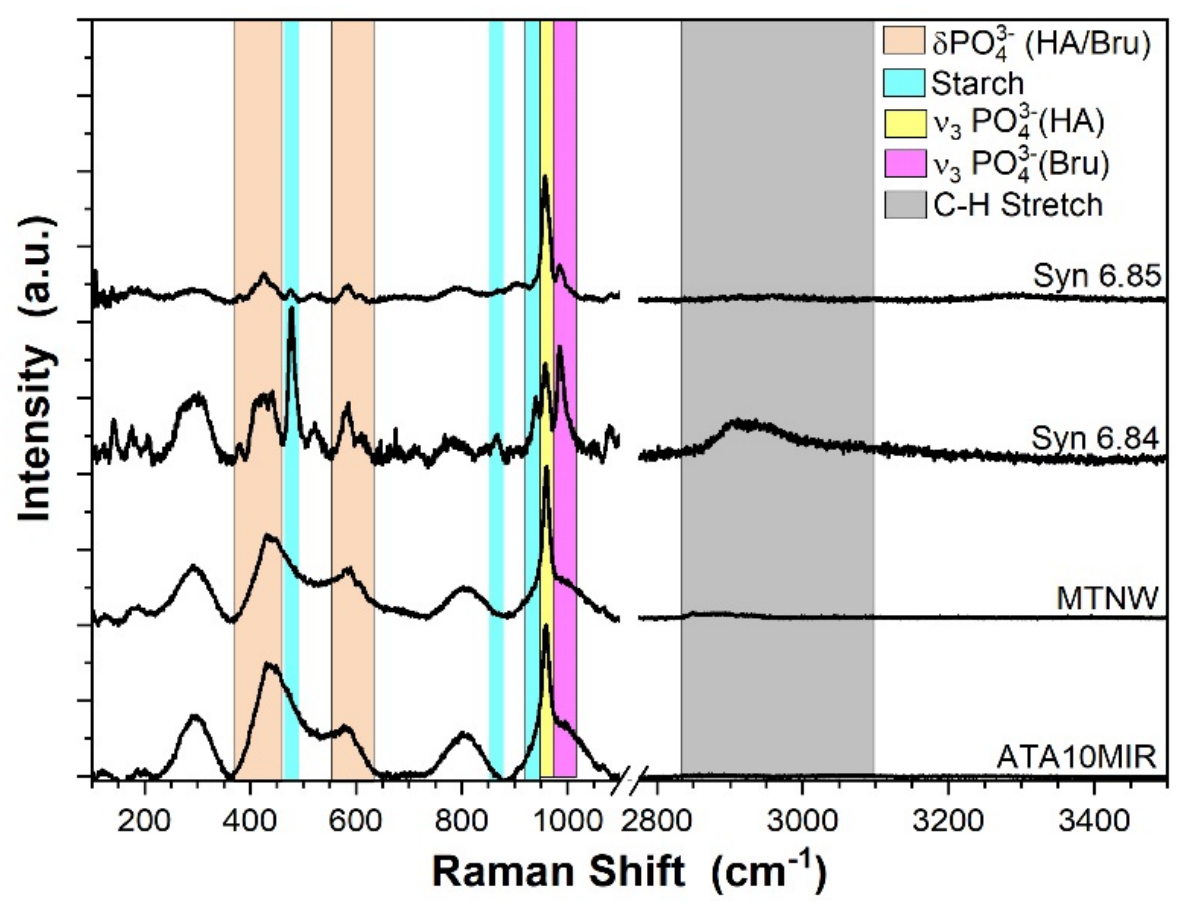

Figure 3 


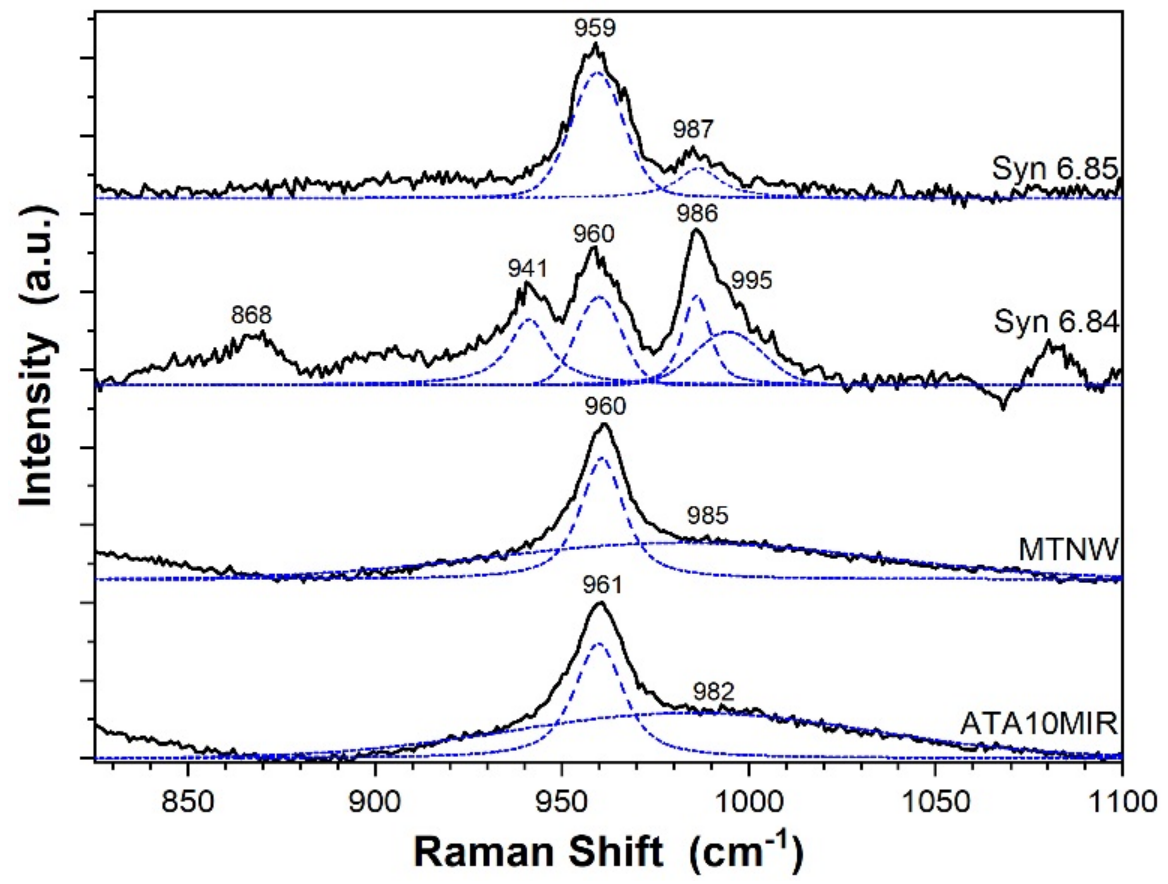

Figure 4 


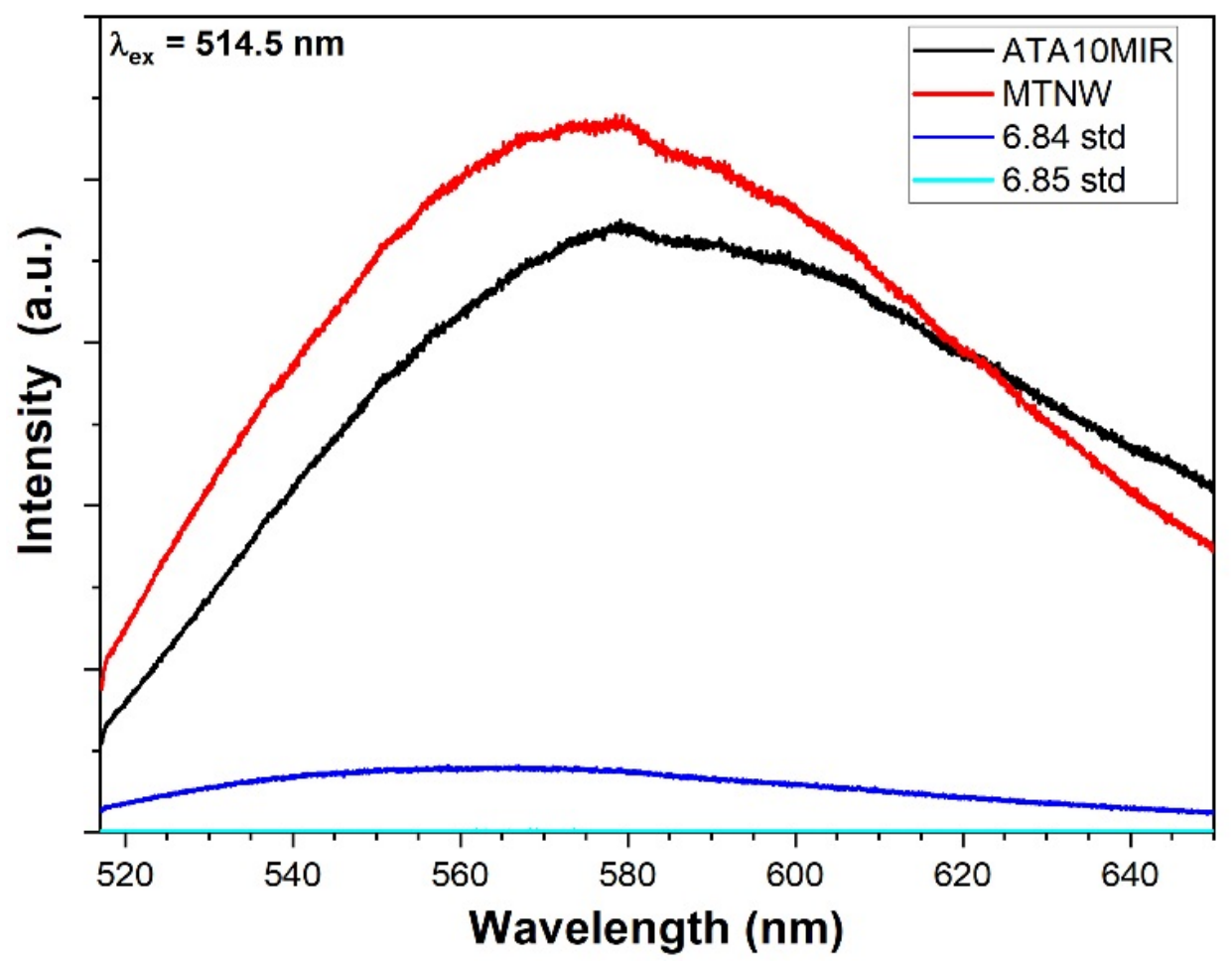

Figure 5 
a
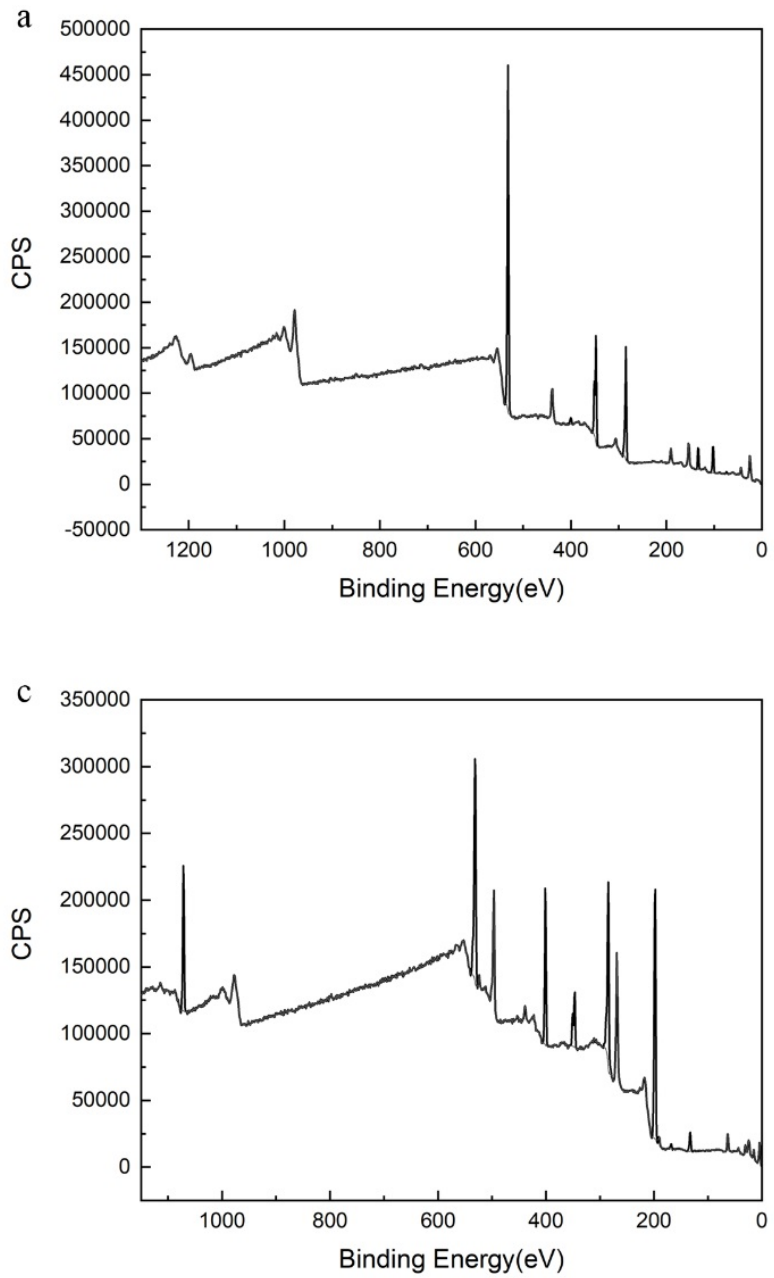

b
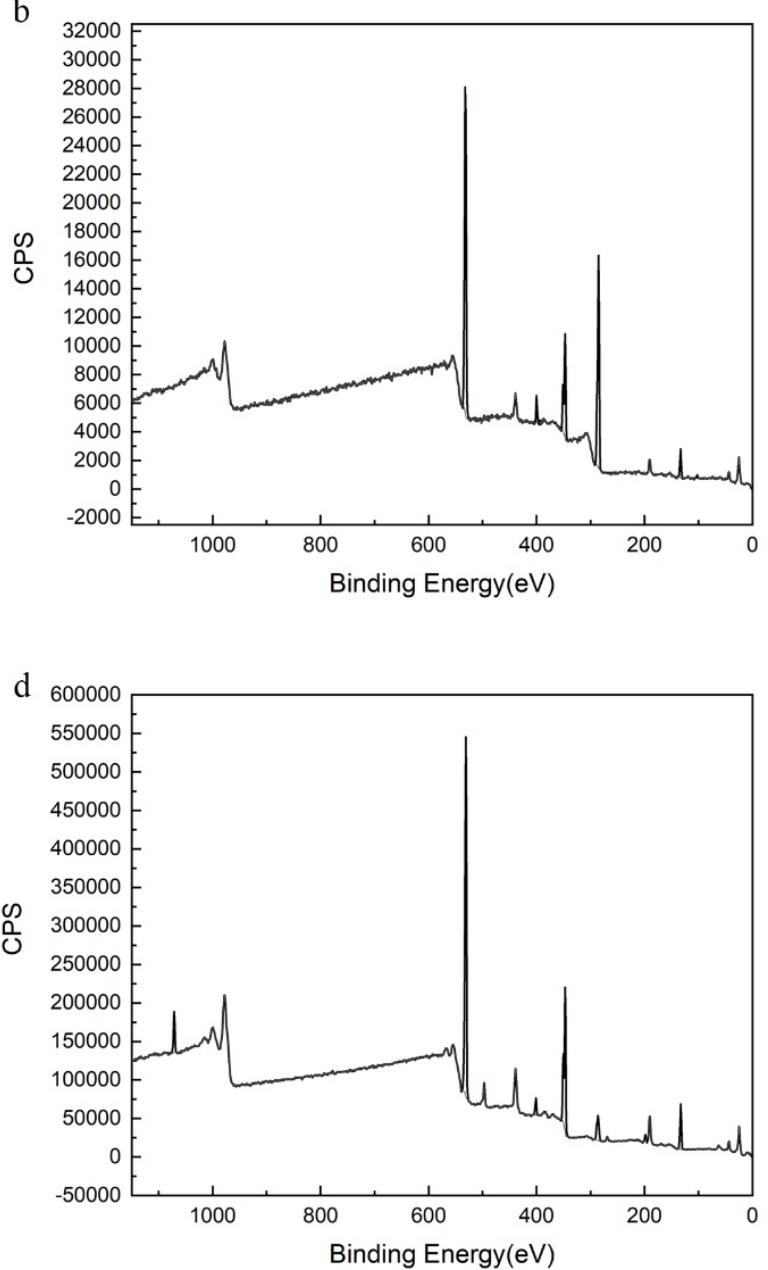

XPS elemental breakdown

Figure 6 
a

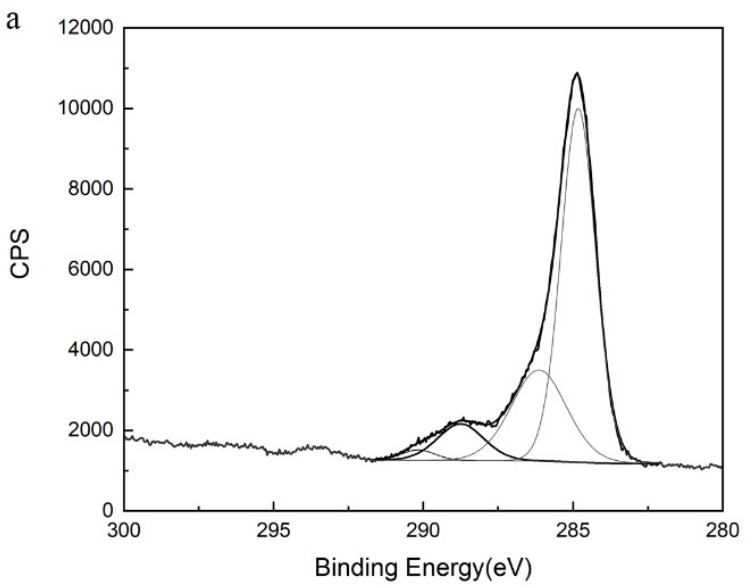

c

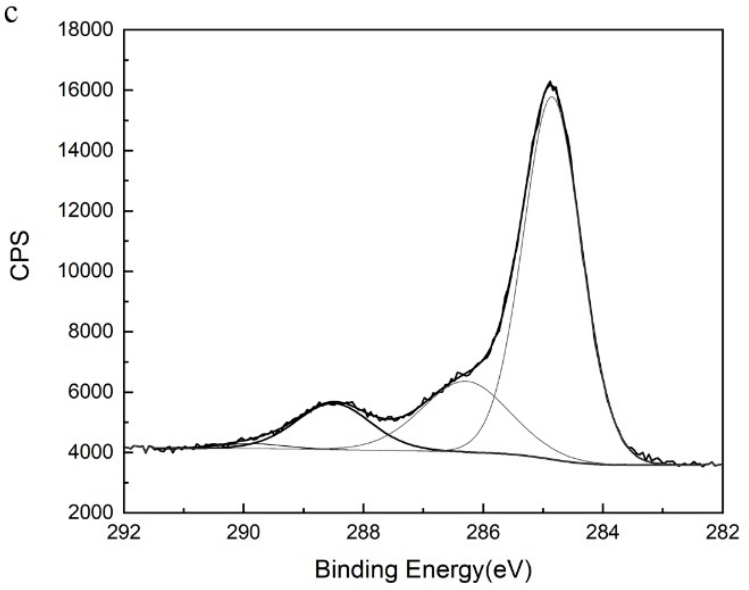

b

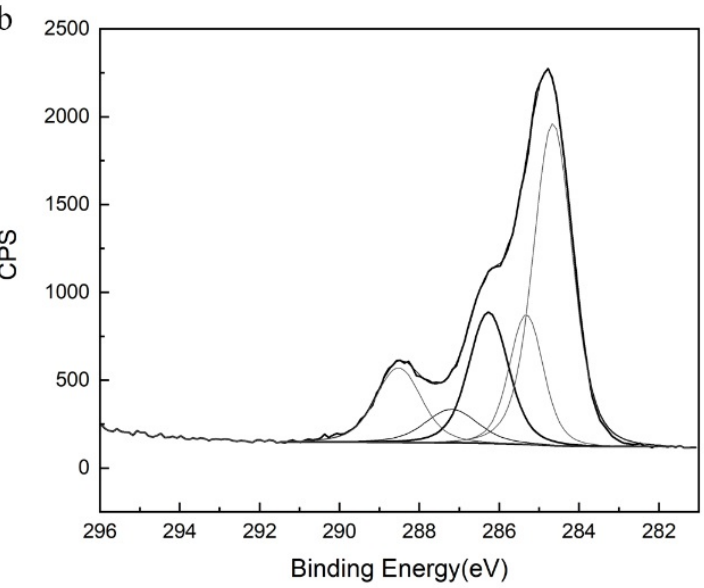

d

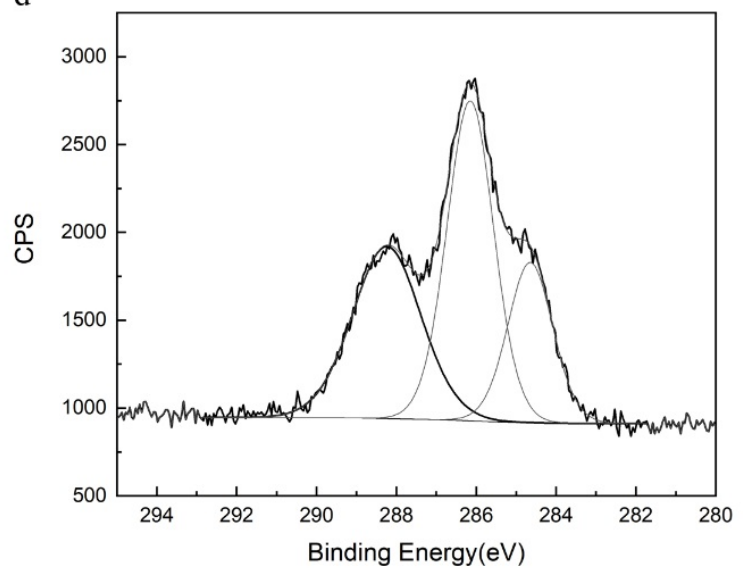

XPS C1s

Figure 7 
a
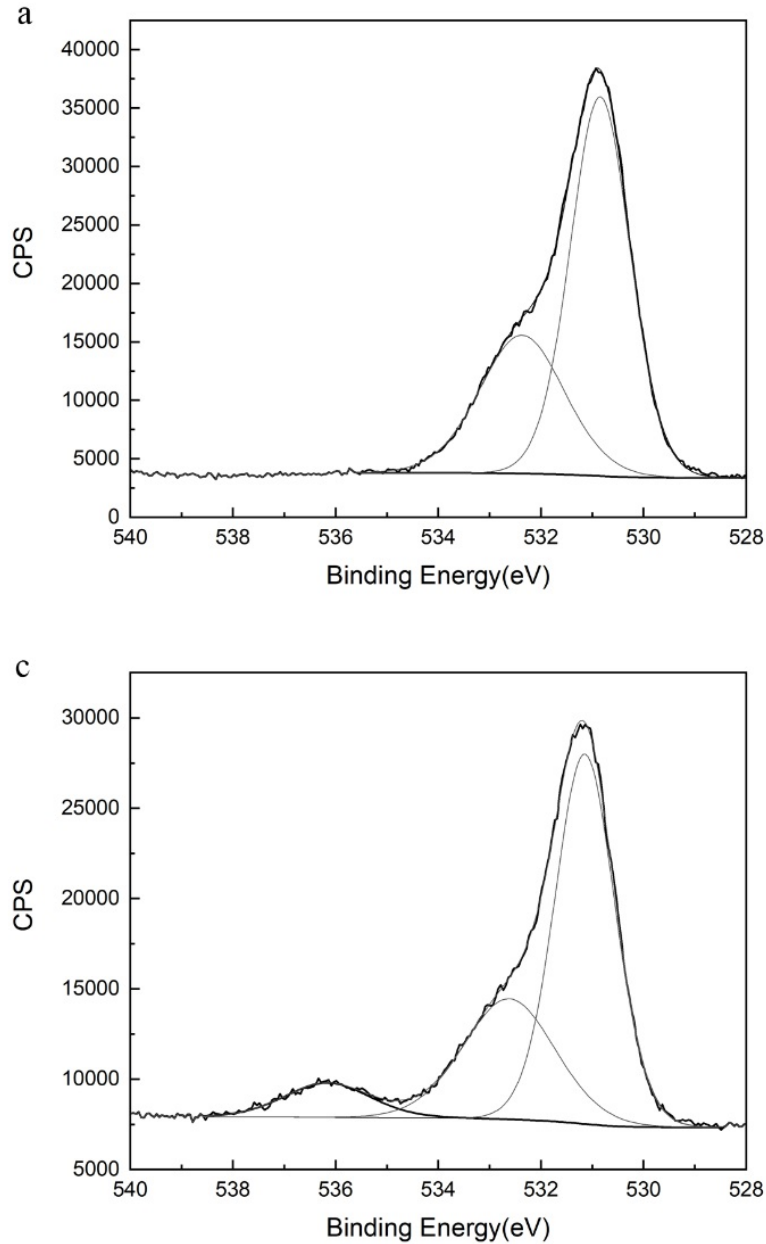

b

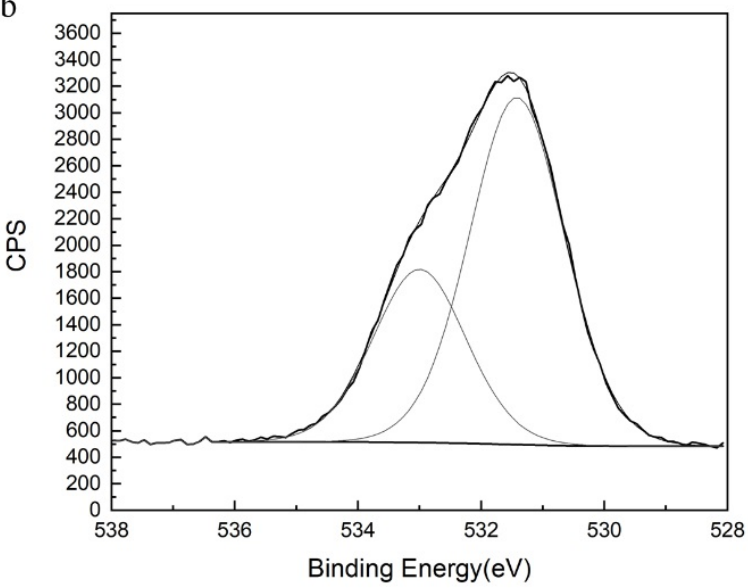

d

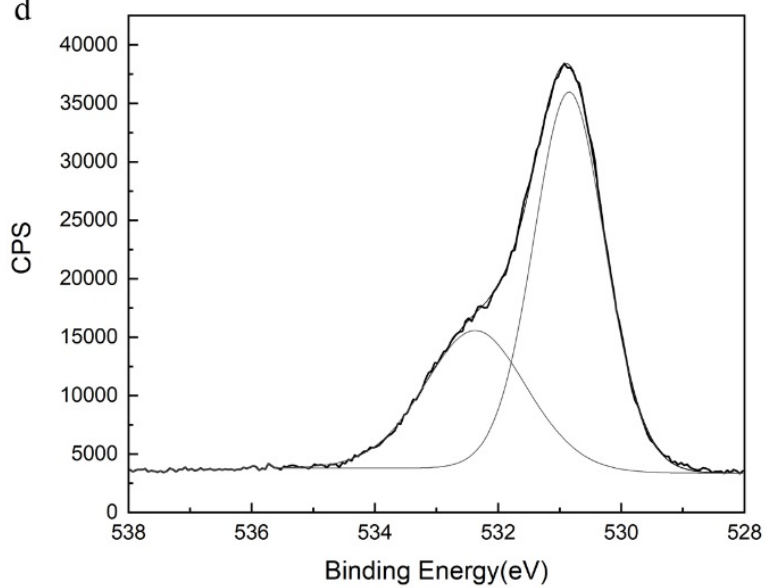

XPS O1

Figure 8 
a
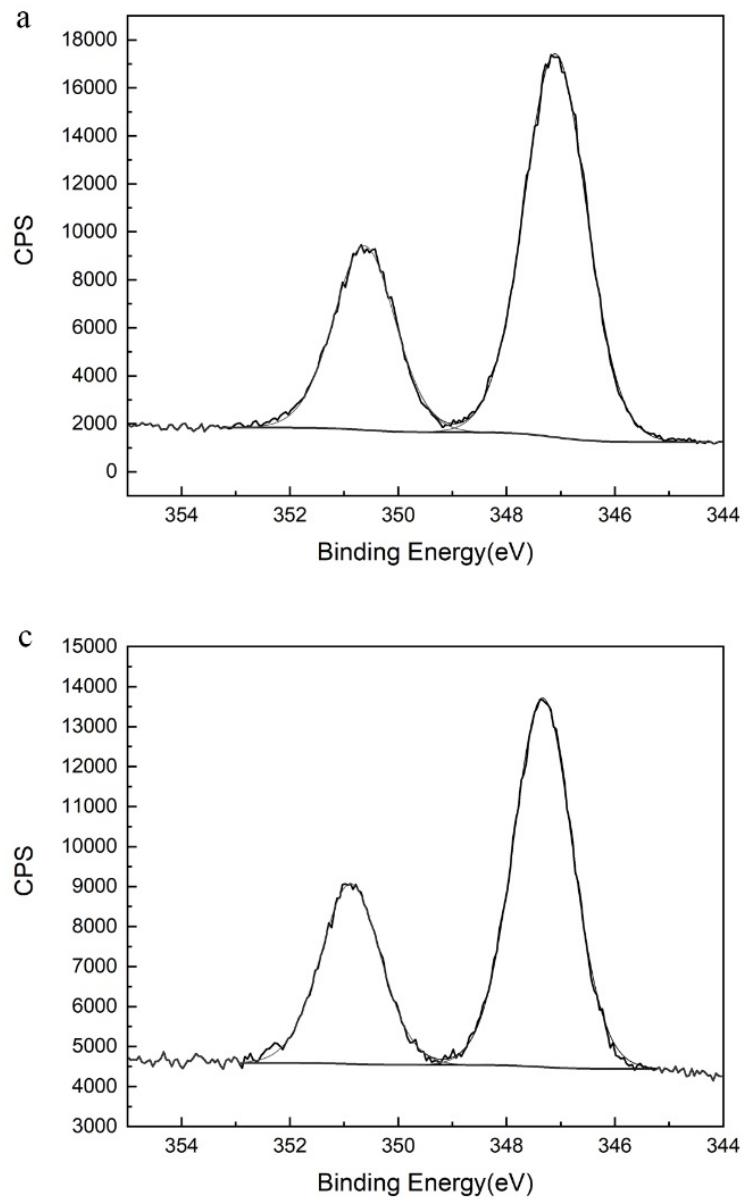

XPS Ca2p

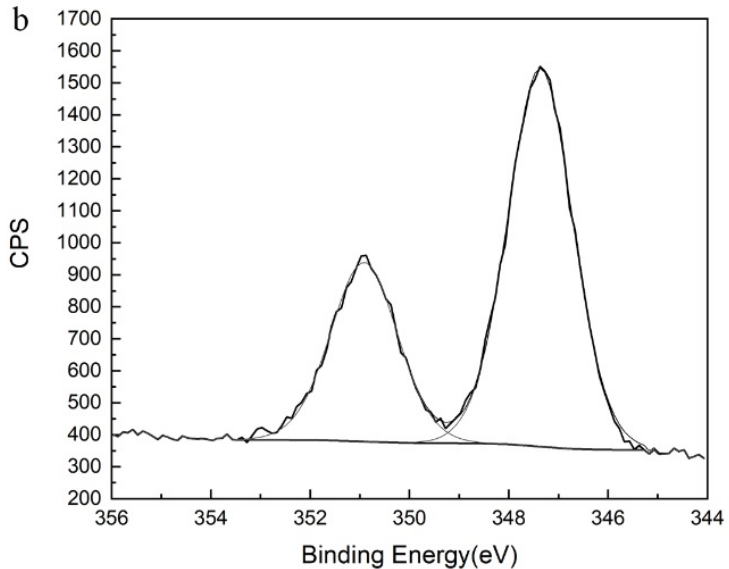

d

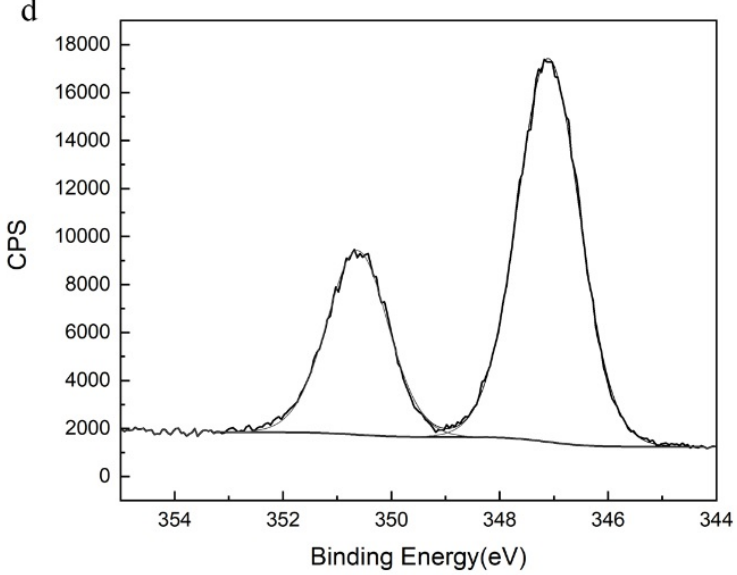

Figure 9 
a
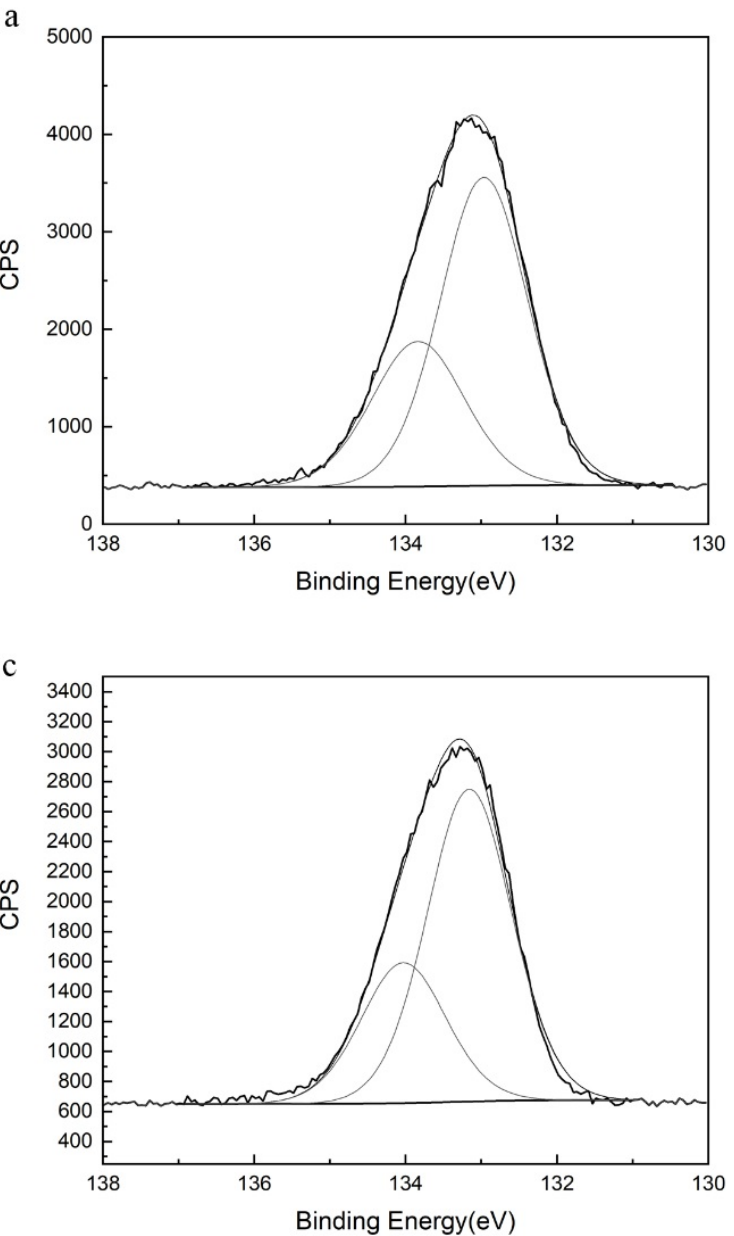

XPS P2p b

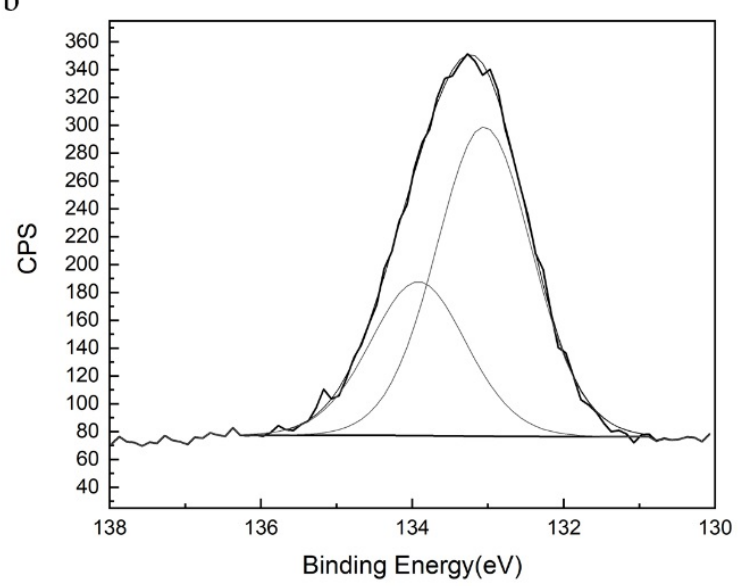

d

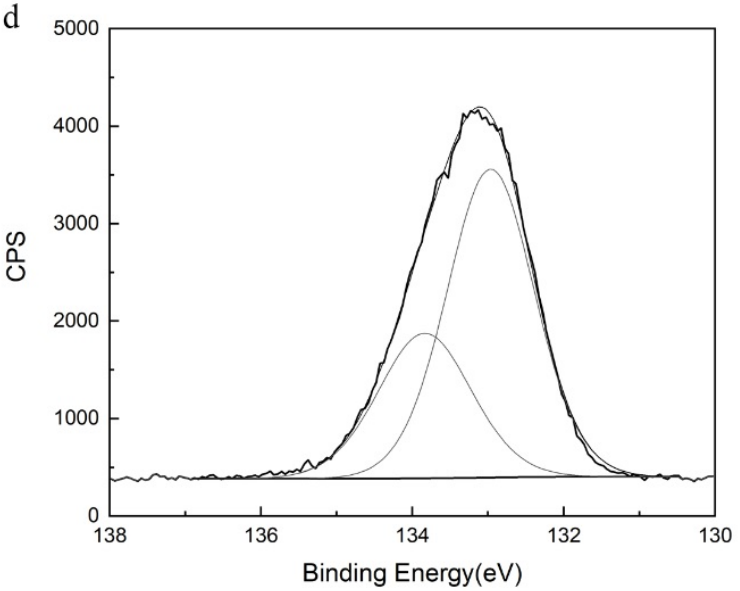

Figure 10 


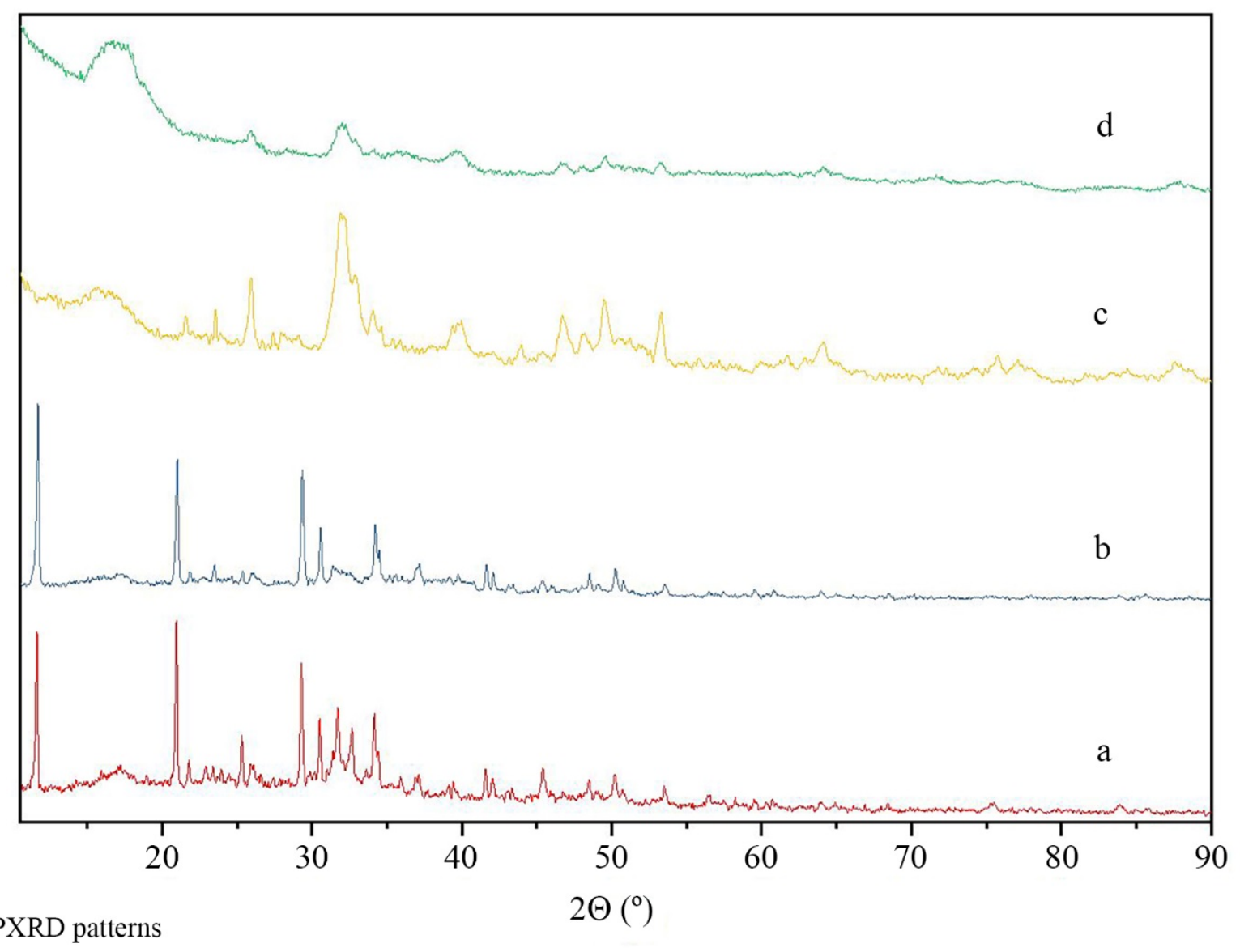

Figure 11 

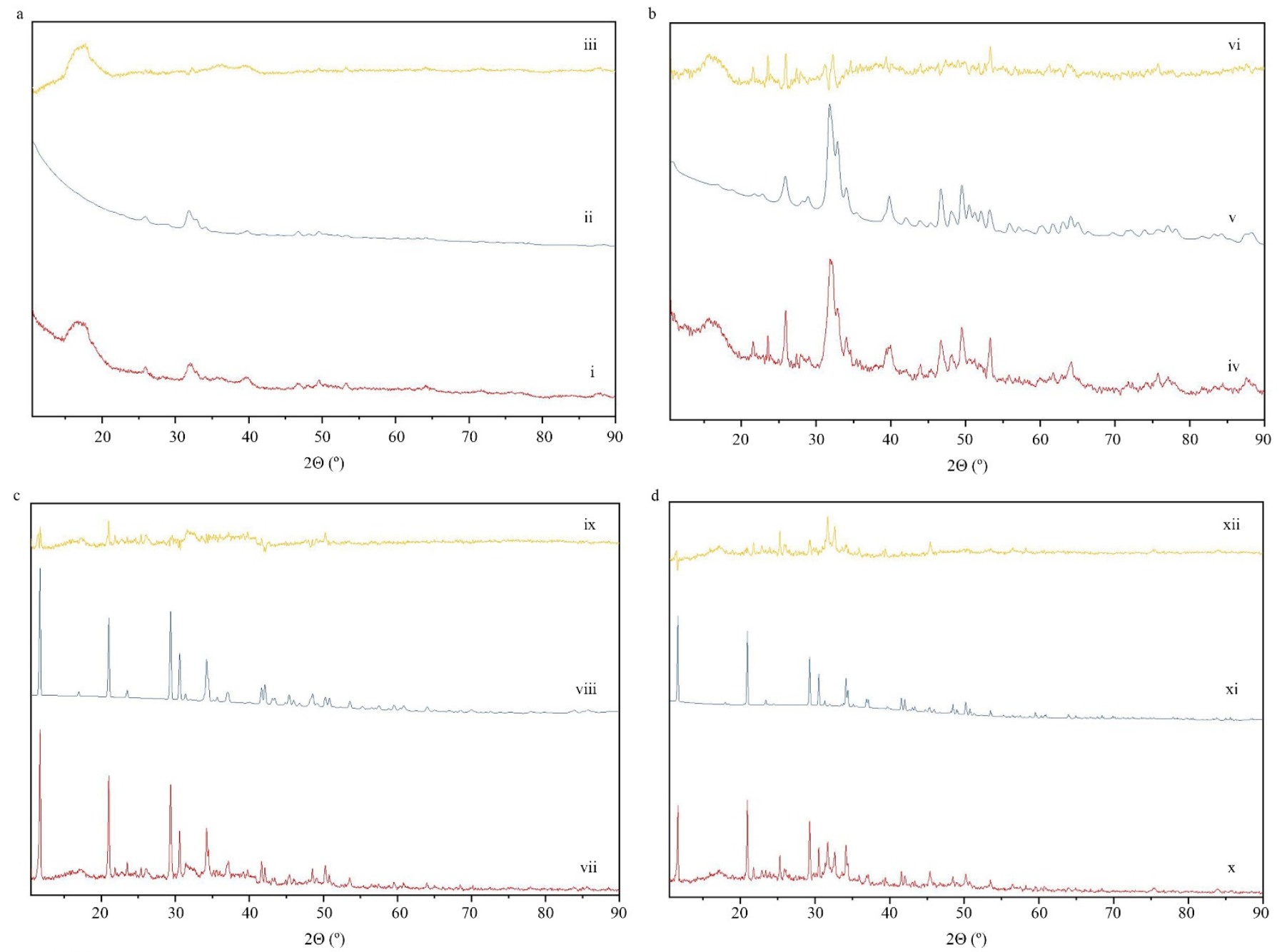

PXRD fitting

Figure 12 

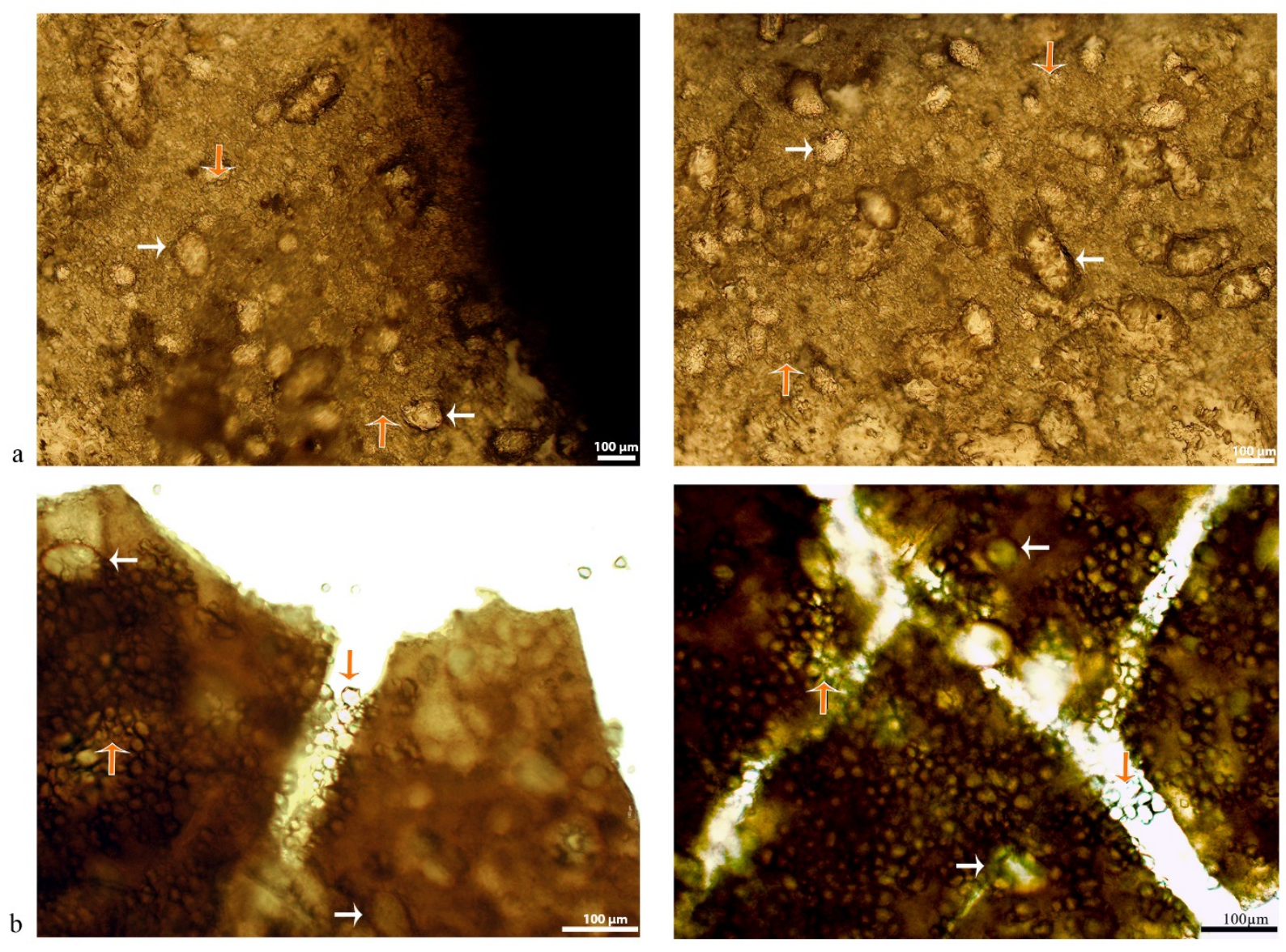

Figure 13 
Calcium hydroxide

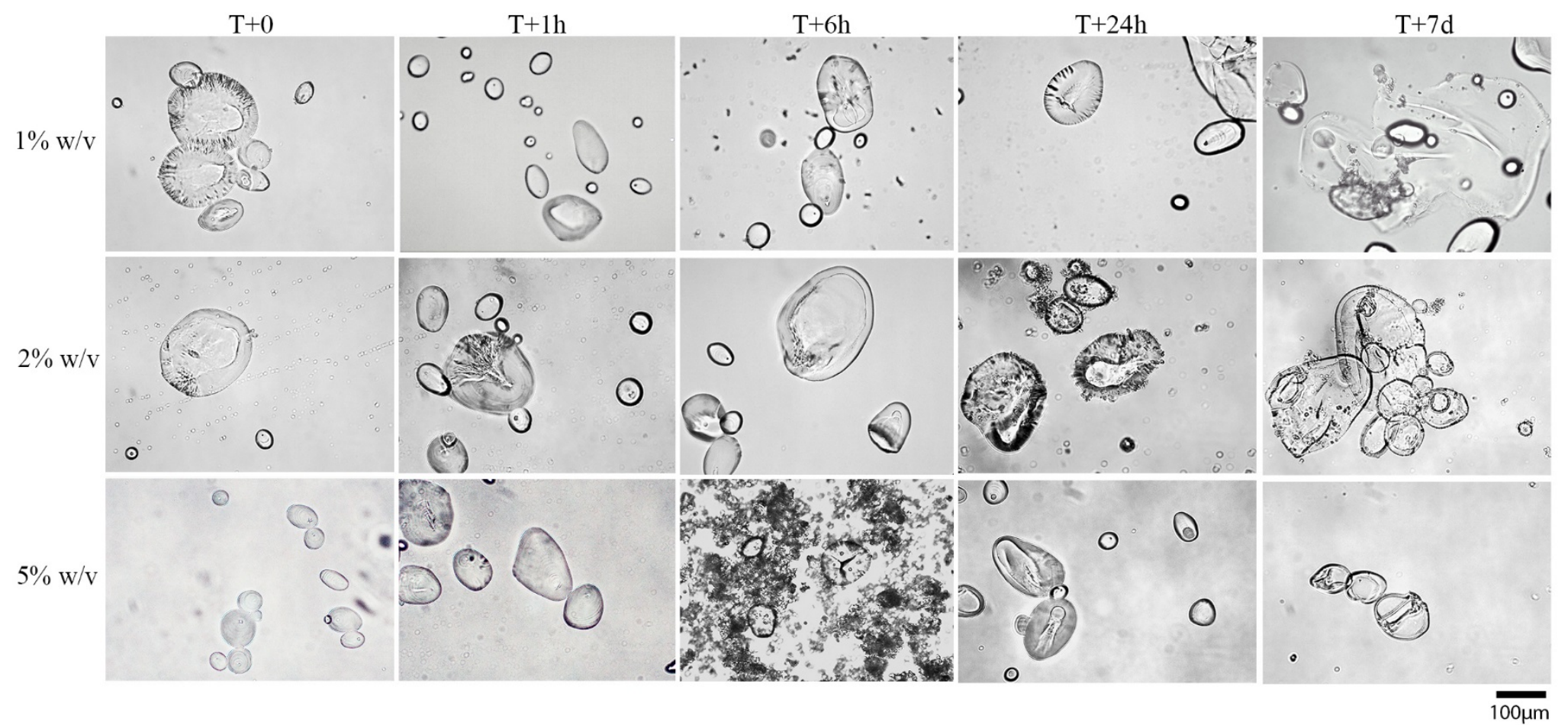

Figure 14 


\section{Calcium hydroxide}

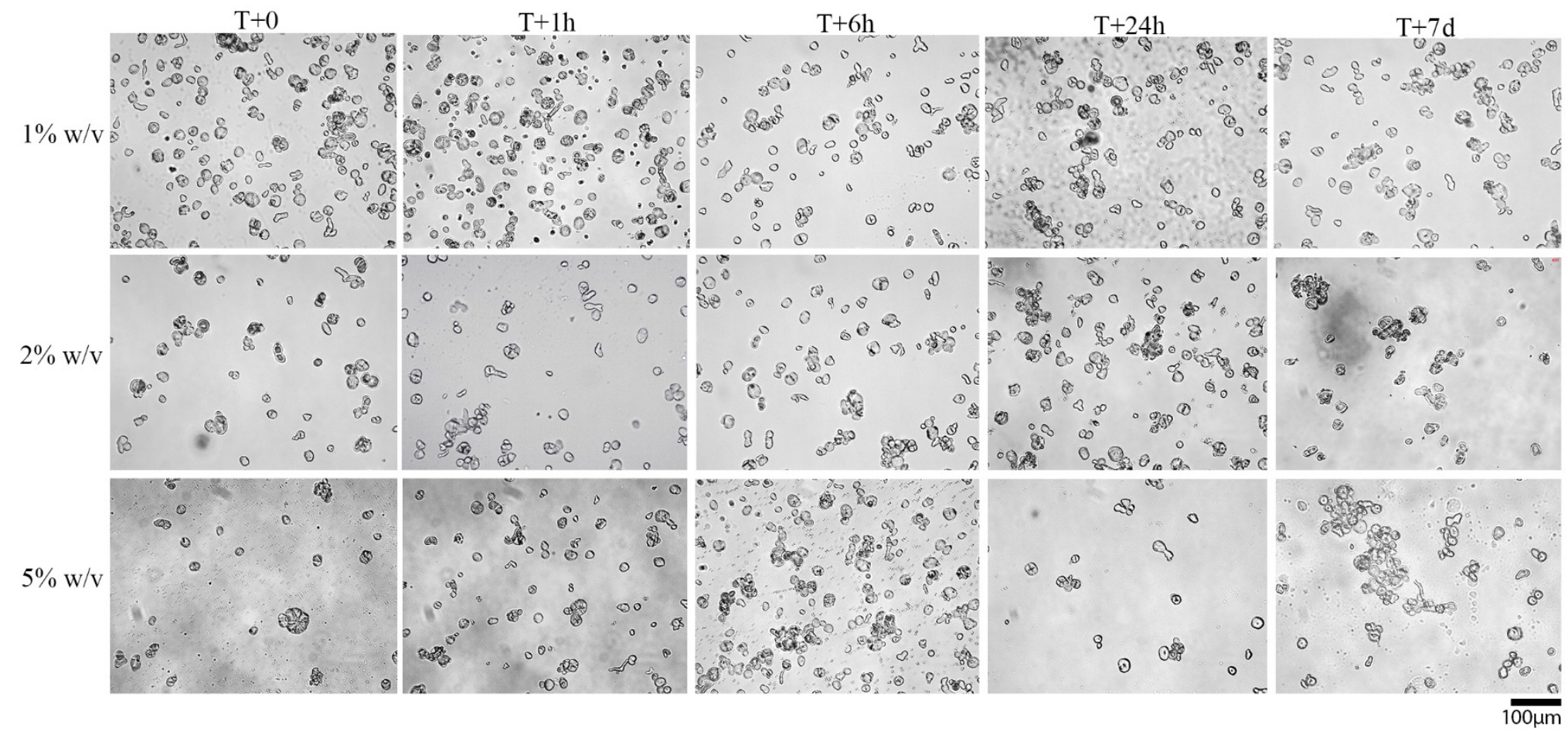

Figure 15 


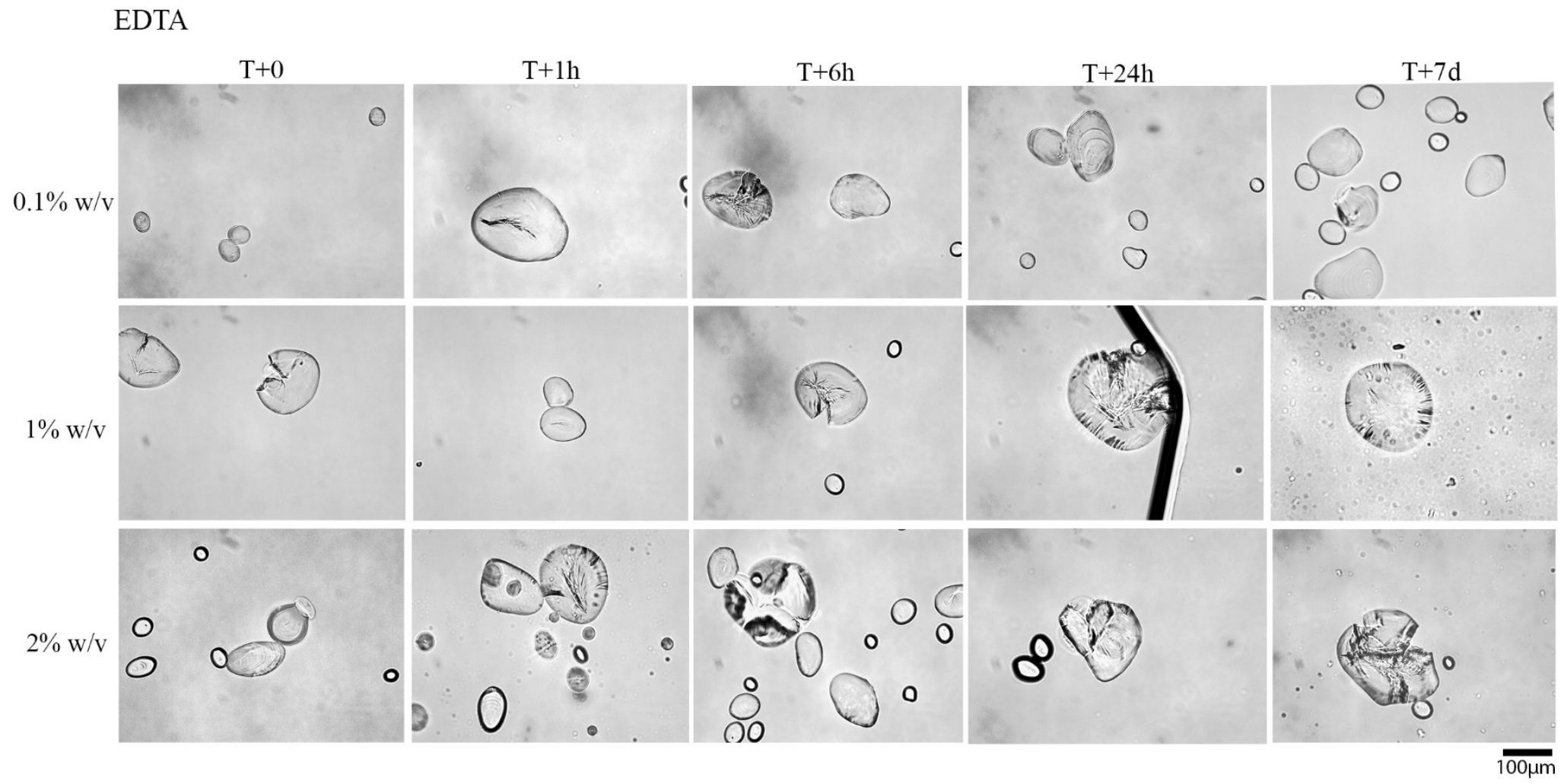

Figure 16 


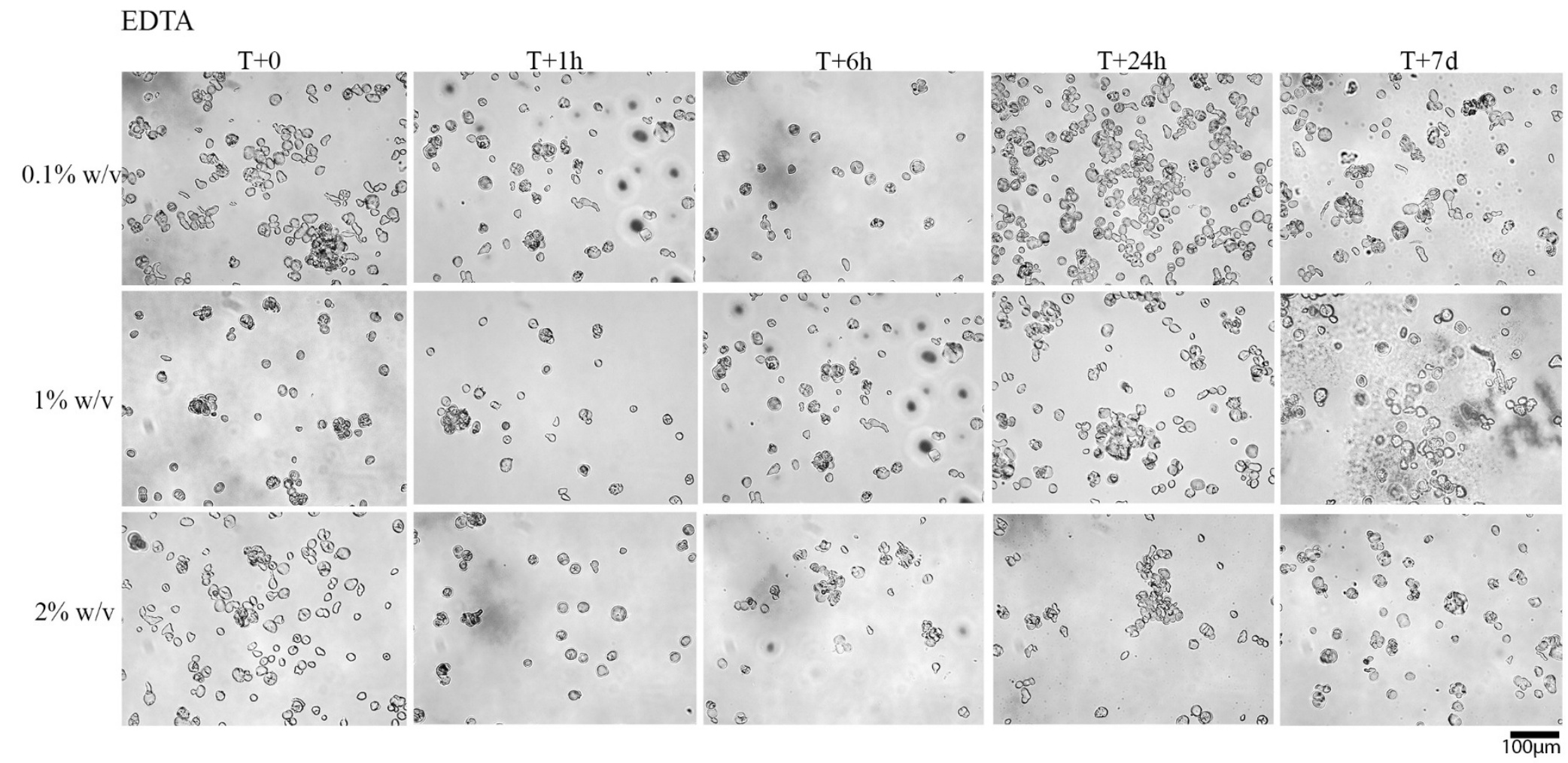

Figure 17 


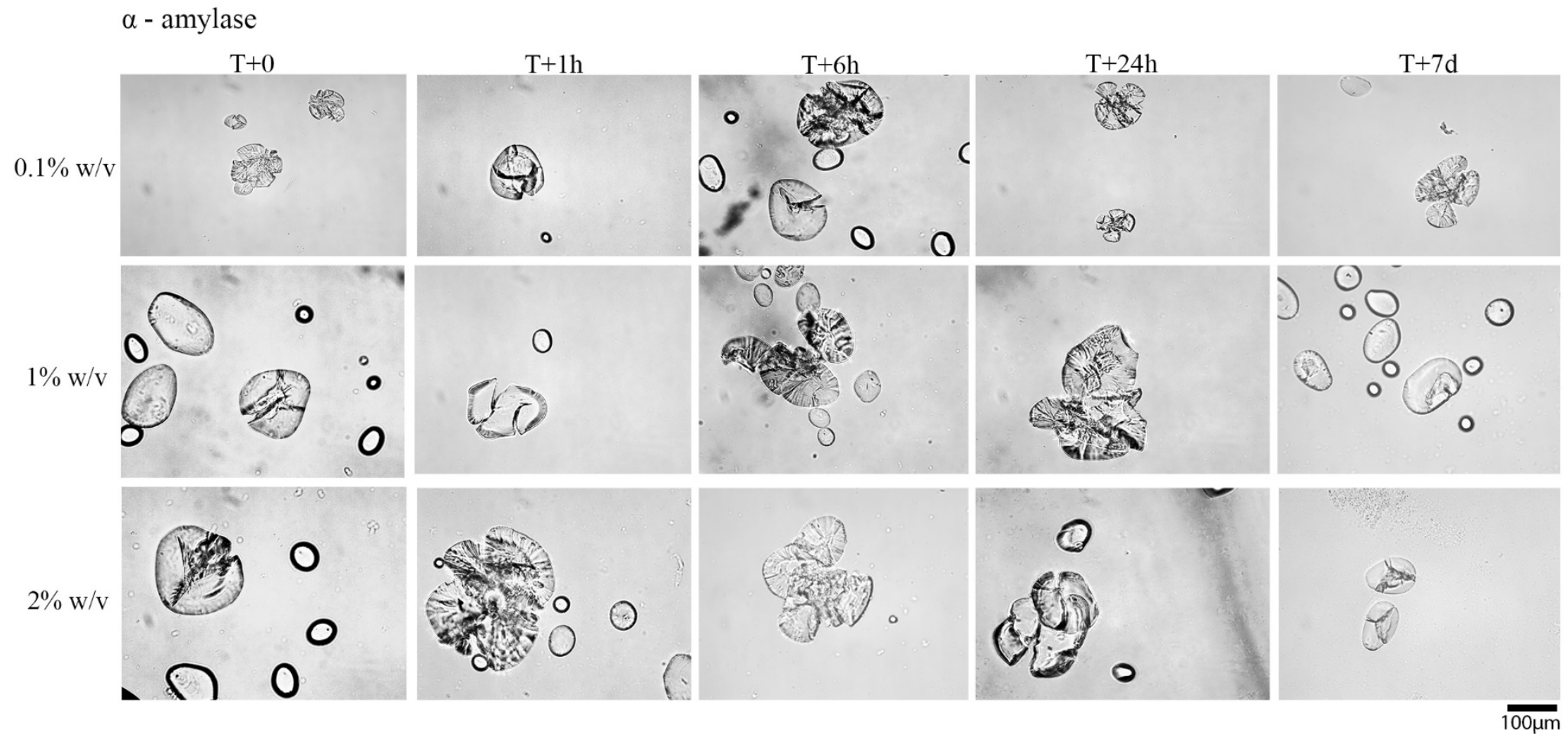

Figure 18 


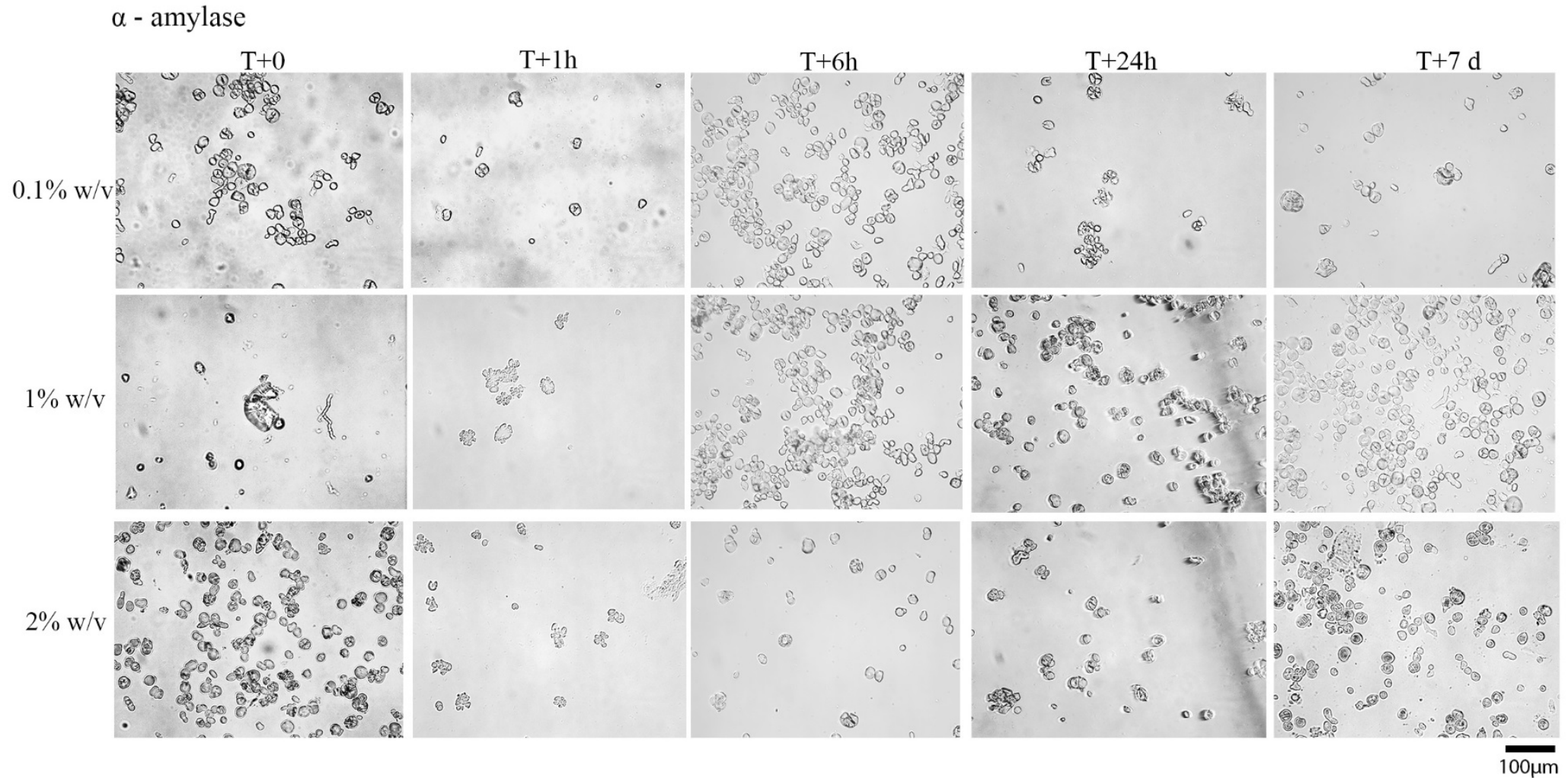

Figure 19 

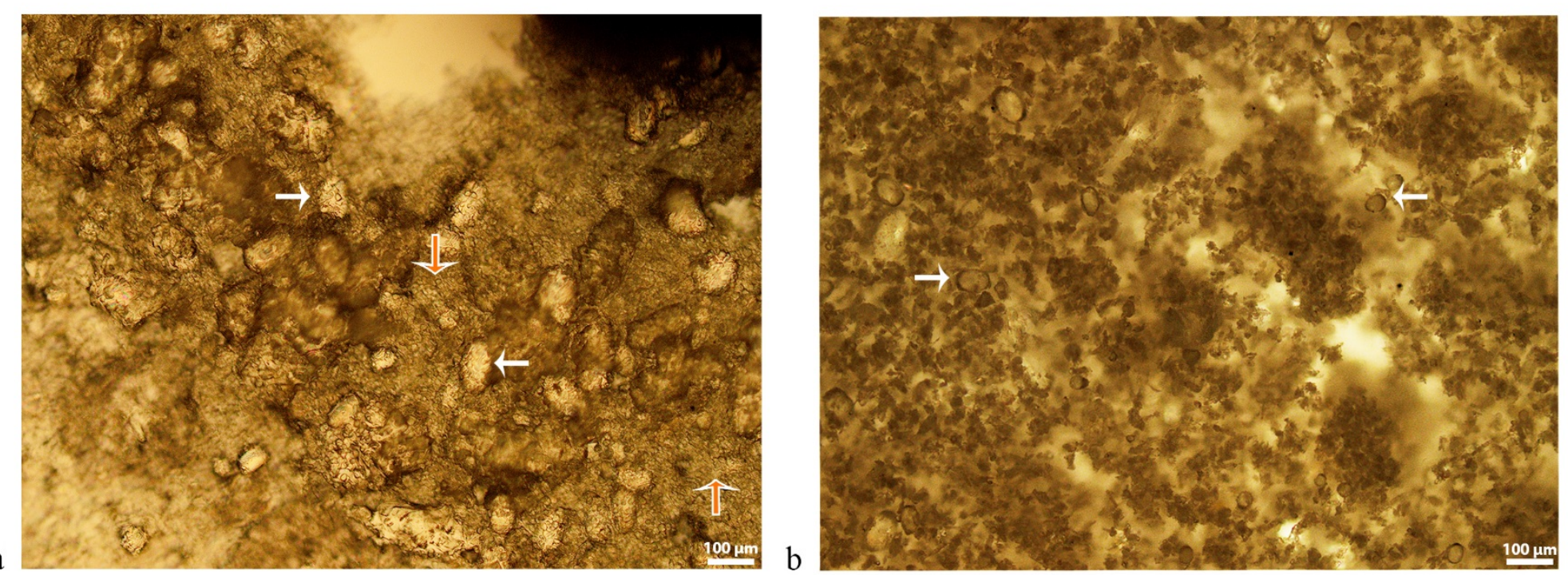

Figure 20 


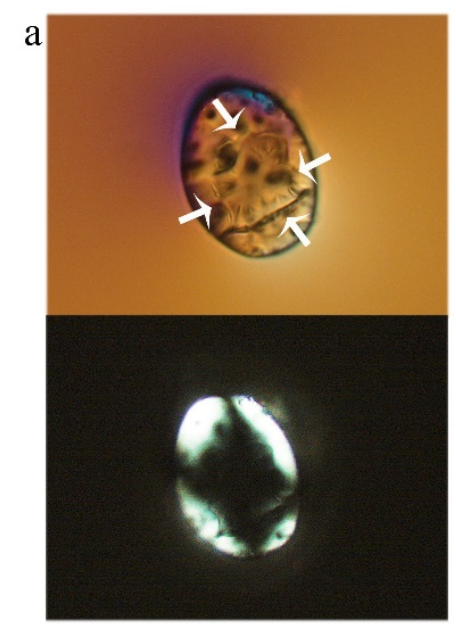

g

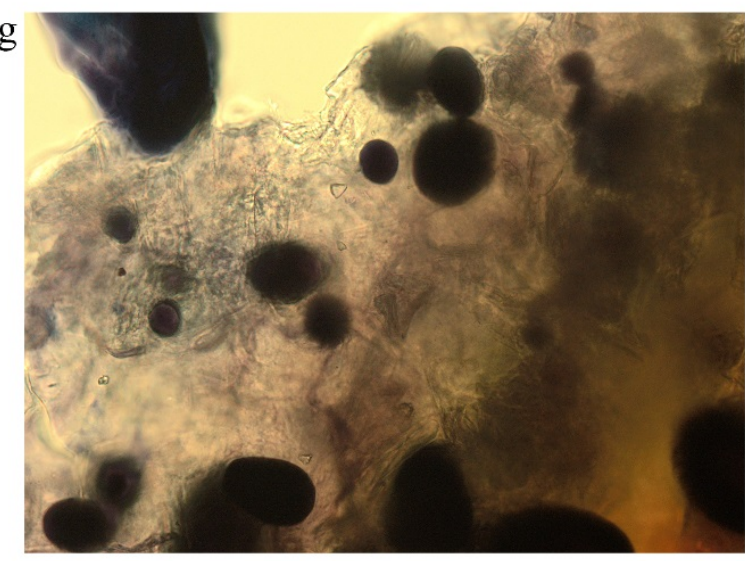

i

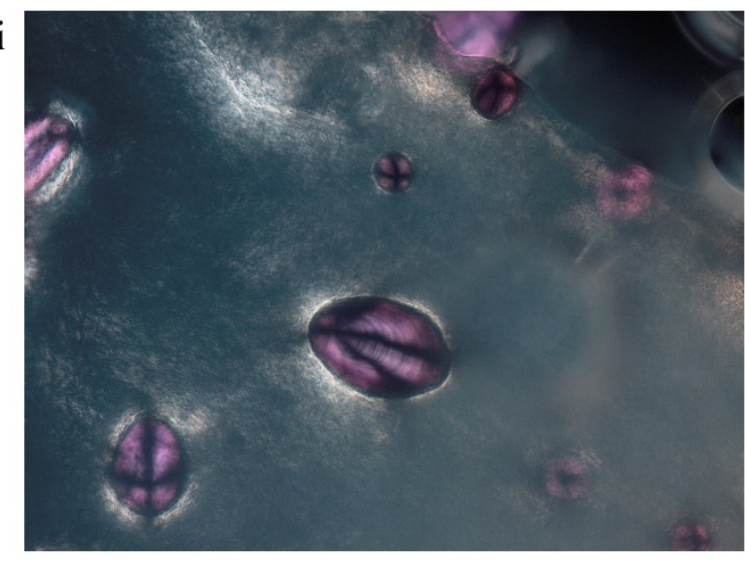

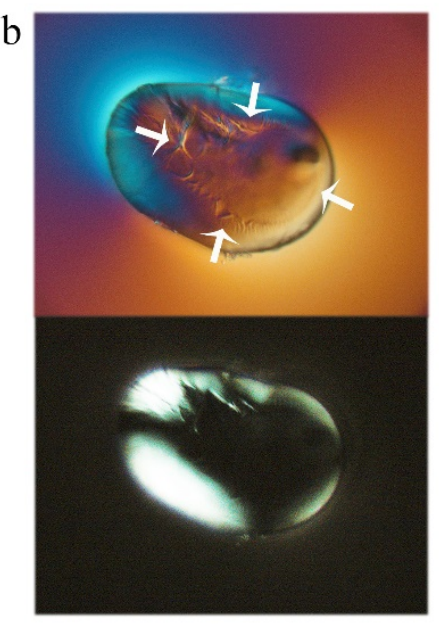
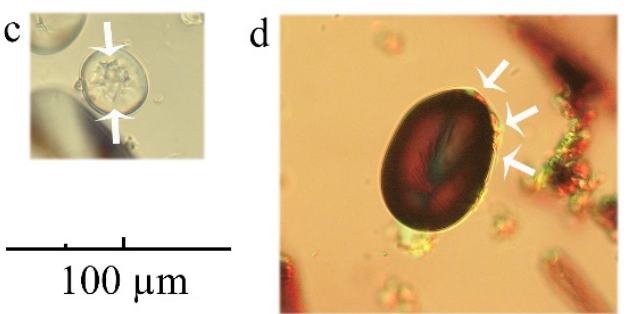

e
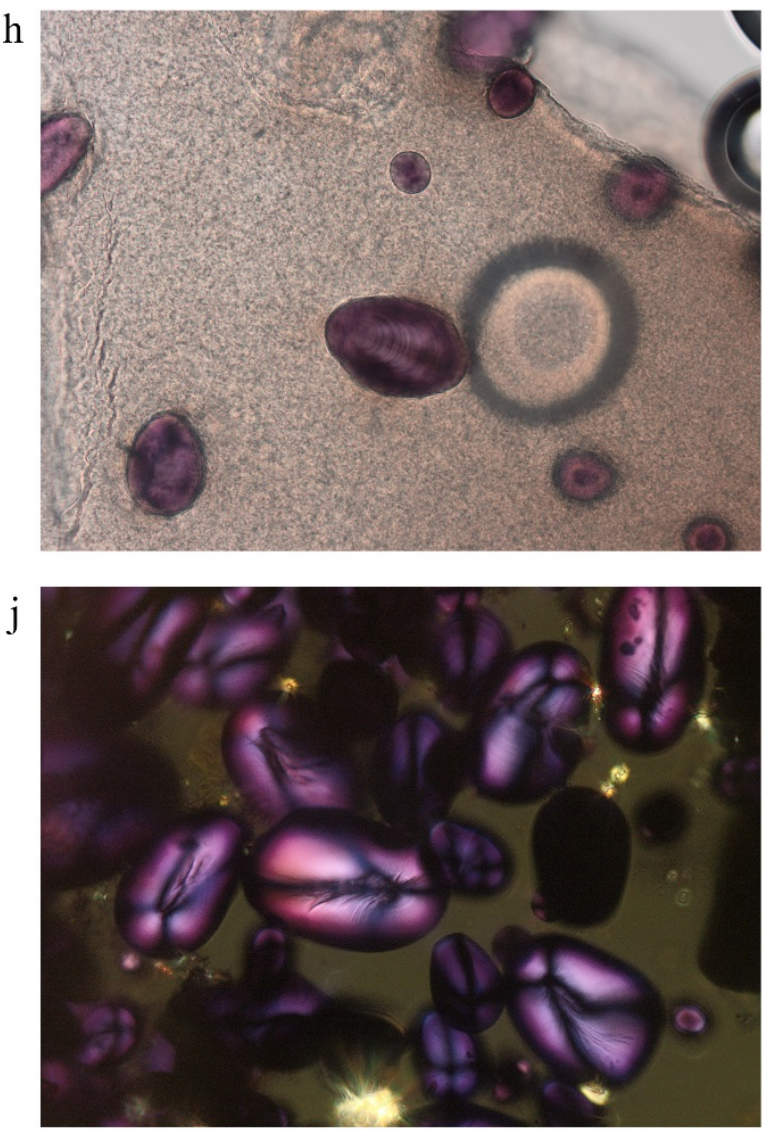

Figure 21 

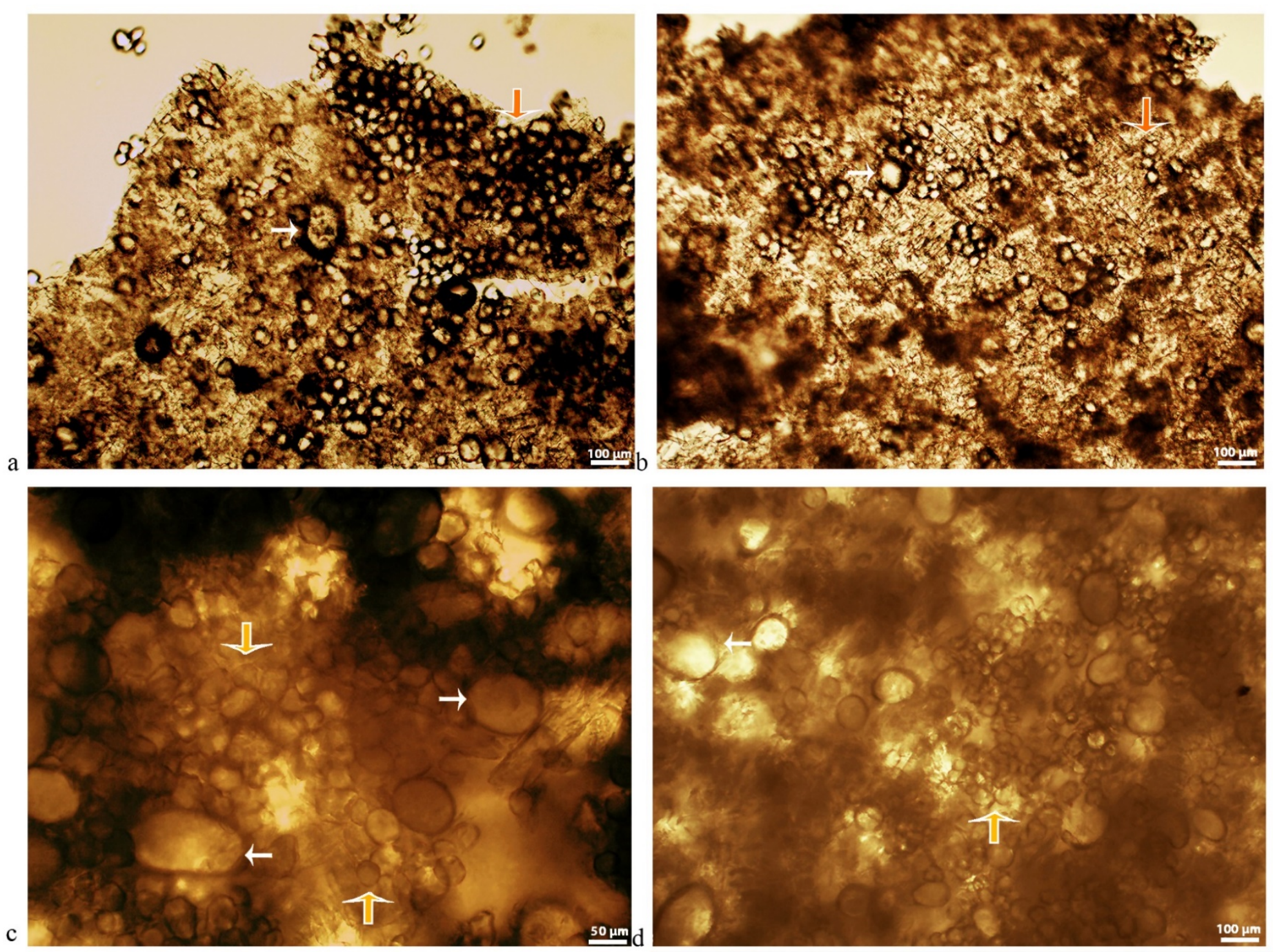

Figure 22 